\title{
Nostalginis diskursas lietuvių memuaristikoje
}

\author{
VILMA POPOVIENÉ \\ Lietuvių literatūros ir tautosakos institutas, Antakalnio g. 6, LT-10308 Vilnius \\ El. paštas vilma.popoviene@gmail.com
}

\begin{abstract}
Straipsnyje, remiantis rusų literatūrologo Ilono Fraimano teorinėmis įžvalgomis ir jo pateikta memuarinių tekstų tipologija, analizuojama lietuvių memuaristikos diskursyvinè raiška (diskurso strategijos), bandant pritaikyti pagal žanro specifiką naratologijos teorinius principus. Diskursas čia suprantamas kaip įvykiu visuma iš tam tikros pozicijos perteikiantis pasakojimas. Analizuojami diskurso fragmentai - konkretūs kalbiniai (gramatiniai) pasakojimo požymiai: 1) nurodantys memuarų rašymo tikslus (intencijas) ir pasakotojo ir / arba veikiančio subjekto požiūrị bei santykị su aprašomuoju objektu, 2) žymintys pasakojimo laiko logikos pažeidimus ir / arba pasakojimo lygmenų pažeidimus, 3) atskleidžiantys vidinès (pasakotojo-veikiančio subjekto) ir išorinès (pasakotojo-adresato) komunikacijos santykį. Straipsnyje apžvelgti literatūrologès Svetlanos Boym teoriniai nostalgijos tyrinèjimai svarbūs analizuojant konkrečius memuarinius tekstus, kuriuose nostalginis pasakojimo pradas yra itin ryškus ir iš esmès veikiantis diskursyvinę jo raišką. Siekiant atskleisti autoriaus (pasakotojo, veikiančio subjekto) santykị su pasakojimo objektu, nagrinèjama nostalgijos, kaip specifinio, su vaizduote susijusio atminties aspekto, raiška. Memuariniuose pasakojimuose veikiančio subjekto sąmonèje nostalgija iškyla įvairiais pavidalais - ir kaip netiesioginè patirtis, formuojanti subjekto santyki su praeities erdvèlaikiu, ir kaip paties subjekto būsena, atsiskleidžianti arba refleksyvia meditacija ir skausmingu iliuzinio objekto ilgesiu, arba praeities atkūrimu ne tik individualioje, bet ir kolektyvineje atmintyje mito ar simbolio pavidalu.
\end{abstract}

Raktažodžiai: memuarinis pasakojimas, diskurso strategija, nostalgija, atmintis, erdvelaikis

\section{IVADAS}

Vakaruose jau kurị laiką itin populiarūs atminties tyrinejjimai pastaruoju metu vis dažniau atsiduria ir Lietuvos mokslininkų akiratyje. Atgavus nepriklausomybę, šia tema rašomi straipsniai, disertacijos, atliekami kolektyviniai moksliniai tyrimai. Atminties kultūra ypač domina istorikus, sociologus, kultūrologus. Tokių tyrimų aktualumas paprastai yra siejamas su atminties paveldo išsaugojimo svarba. Šiuolaikinei globalizacijos, modernių 
technologijų ir vartotojiškos kultūros formuojamai visuomenei tampa ypač svarbu išlaikyti savojo aš tęstinumą, istoriškai ir kultūriškai ịprasminti žmogiškąją būtị, atkurti (ar naujai sukurti) kad ir fragmentuotą savo tapatumą.

Prancūzų istorikas Pierre’as Nora tokị „atminties eros“ suklestejjimą pirmiausiai sieja su istorinio laiko sampratos kaita, arba „istorijos akceleracija“, lemmusia vientiso tiesiaeigio praeitị, dabartị ir ateitị jungiančio bei ịprasminančio laiko idejjos žlugimą, iškèlusia „pareigos atminčiai“ svarbą (1). Atotrūkis nuo praeities, pasak P. Nora, yra toks didelis, kad ji mums nebeegzistuoja, o tik reiškiasi tam tikrais ženklais ar liekanomis - toks praeities praradimo, netekties pojūtis lemia kartais net hipertrofuotą atminties sureikšminimą, siekiant bent iš dalies rekonstruoti ši „prarastą pasaulį":

Jei praeitis jau nèra ateities garantas, tai atmintis užtikrina tam tikrą tęstinumą ir ima vaidinti itin svarbu vaidmeni. Seniau vyravo praeities ir ateities vienove, kuria dabartis tik sutvirtindavo, o šiandien dabartis veikia išvien su atmintimi (2).

Kitas istorinis veiksnys, pasak teoretiko, stipriai paveikęs atminties proverži, yra socialinio pobūdžio, susijęs su tautų, etninių, socialinių grupių ir atskirų individų išsilaisvinimo judeji$\mathrm{mu}$, kai praeities atkūrimas tampa integralia tapatumo ịtvirtinimo dalimi. P. Nora išskiria tris dekolonializacijos tipus, jo nuomone, lemusius ịvairių kolektyvinès ir individualios atminties formų sklaidos intensyvejimą. Pasaulinè dekolonializacija susijusi su tautinę stagnaciją išgyvenusių visuomenių istoriniu sąmonėjimu ir atminties atkūrimo arba sukūrimo poreikiu. Vidiné seksualinių, socialinių, religinių, provincijos mažumų dekolonializacija atvèrè joms integracijos ir tapatumo ịtvirtinimo viešumoje galimybes. Šis kelias, pasak P. Nora, būdingas klasikinei Vakarų visuomenei. Trečiasis dekolonializacijos tipas - ideologine dekolonializacija - atsirado griuvus XX a. totalitariniams režimams ir sudarė prielaidas išsivadavusioms tautoms „susigrąžinti tradicinius, senus prisiminimus, kuriuos tie režimai buvo pasisavinę, sunaikinę arba jais manipuliavo“ (3).

Šios aplinkybès lèmè memuarų žanro suklestejjimą pastaraisiais dviem dešimtmečiais ir Lietuvoje. Memuarinio pobūdžio knygos čia gausiai rašomos ir su malonumu skaitomos, nors literatūrologų vis dar menkai reflektuojamos. Vis dèlto ilgą laiką literatūros periferijoje buvęs žanras tampa aktualus ne tik dèl savo istorinio informacinio turinio (kuris skaitytojui ir toliau išlieka svarbiausias), bet vis dažniau sulaukia ir mokslininkų dèmesio dèl specifinių pasakojimo ypatumų. Keičiasi ne vien išorinis memuaristikos vertinimas bei suvokimas, kinta ir paties žanro, iki šiol laikyto gana siauru, vidinè struktūra. Čia neabejotinai svarbi rašančiojo pozicija. Memuarų rašytojas, dažnai net nesusijęs su profesionalaus rašymo sritimi, yra sąlygiškai laisvas, nevaržomas žanro reikalavimų. Tiesiog rašydamas „taip, kaip buvo“, jis pats kuria naujas memuarinio pasakojimo formas. Taip memuarų žanras plečiasi, transformuojasi, persipina ne tik su sau artimais žanrais - autobiografija, dienoraščiais, laiškais, esè - susijusiais bendromis atminties, patyrimo, erdvélaikio, tapatumo kategorijomis, bet ir igauna grožinei literatūrai - novelei, apsakymui, romanui - būdingų bruožų bei tarpdalykinių sąsajų su ịvairiomis mokslo sritimis - filosofija, istorija, religija, menu ir pan. Skirtingos pasakojimo formos (deskriptyvumas, chronologiškumas, asociatyvumas, siužetiškumas), autorių intencijos (noras nuosekliai papasakoti savo gyvenimo istoriją arba tik išryškinti svarbiausius gyvenimo įvykius, siekis apmąstyti praeitị ir savosios būties reikšmę arba autentiškai atkurti
(1) $[13,14-15]$.
(2) $[13,16]$.
(3) $[13,17]$. 
faktinę medžiagą, paliudyti reikšmingus ịvykius), taip pat individuali rašančiojo stiliaus raiška leidžia atsirasti daugybei žanrinių variacijų (memuarinis dienoraštis, memuariné-autobiografinè proza, memuarinis esé, memuariné apybraiža, gyvenimo, kelioniu užrašai, meditacinė memuaristika) (4). Memuarinis tekstas tampa sudètinga, daugialype, nestabilia struktūra, kaskart reikalaujančia atnaujinti sąvokų ir klasifikacijos apibrěžtis. Negana to, prigimtinė memuaristikos dichotomija, kai greta atsiduria istoriškumas (orientacija $\mathfrak{i}$ atmintị ir turinị) ir literatūriškumas (orientacija ị vaizduotę ir formą), neišvengiamai sukelia tam tikrų metodologinių problemų. Tarpdalykinėje tyrimų erdvejje gerokai įvairuoja ne tik paties žanro ir jo ribų definicijos bei atskirų sąvokų vartojimas, bet ir tyrimų tikslai, strategijos, metodologinès prieigos. Šiame straipsnyje žanro ribos ir definicijos nebus probleminamos.

Bet kuriuo atveju skaitant ir tiriant memuarinius tekstus svarbu atsakyti i klausimus, $k a s$ (pasakotojo, veikiančio subjekto pozicija), $\boldsymbol{k q}$ (pasakojimo objektas), $\boldsymbol{k a i p}$ (pasakojimo strategija) ir kodèl (motyvas, intencija) atsimena. Šie klausimai suponuoja dvi galimas iš esmès opoziciškas memuaristikos tyrinéjimų kryptis: pasakojimo turinio analizę, kuri produktyvi memuarinius tekstus panaudojant kaip alternatyvų informacijos šaltinį, ir pasakojimo formos, arba diskurso, analizę. Pastaroji pozicija sutampa su literatūrologine žiūra, t. y. memuarų kaip naratyvo traktavimu. Nors dèl memuarų žanrinès specifikos, reikalaujančios individualios prieigos prie kiekvieno atskiro teksto, kiek komplikuojasi vieningo metodologinio instrumentarijaus parinkties klausimas, straipsnyje iš esmès bandoma laikytis prancūzų naratologijos suformuotos teorinès perspektyvos.

Diskursyvini pasakojimo lygmenị nagrinëjanti naratologija dèmesị sutelkia į pasakojimo formą, svarstydama, kaip pateikiama naratyvinè informacija arba pasakojimo turinys. Remdamasis Vladimiro Propo, Tzvetano Todorovo ir Algirdo Juliaus Greimo teorinemis ižvalgomis, Roland’as Barthes’as išskiria tris tarpusavyje susijusius pasakojimo lygmenis: funkciju, veiksmų ir naracijos (5). Funkcijų lygmenị čia sudaro naraciniai vienetai (pagrindinès funkcijos - branduoliai, papildančios funkcijos - katalizès) ir požymiai (semantiniai požymiai, informaciniai požymiai, arba informantai). Veiksmų lygmuo susijęs su pasakojimo siužetu ir veikiančiais subjektais. Naracijos lygmenyje išryškèjantys pasakojimo ženklai funkcijas ir veiksmus integruoja ị naracinę komunikaciją tarp autoriaus (pasakotojo) ir skaitytojo. Šie trys R. Barthes'o išskirti pasakojimo lygmenys neatsiejamai sąveikauja tarpusavyje, susijungdami ì prasmingą teksto turinio ir formos visumą.

Gerardo Genetteo pasakojimo analizè (6) taip pat apima tris plotmes: istorija (histoire) - pasakojamų ivvykių visumą; pati pasakojima siauraja prasme (recit) - ivvykius pasakojanti diskursą; pasakojimo akta (narration) - situaciją, kurioje pasakojimas pasakojamas. Teoretiko teigimu, naratyvinis diskursas (arba ịvykius pasakojantis tekstas) neišvengiamai konstruojamas per pasakojimo aktą, kuris taip pat tiesiogiai igalina ir pasakojimo turinị (7). G. Genetteo naratologijoje diskurso analizė suprantama kaip sąveikos tarp šių trijų plotmių nustatymas. Pasakojimo struktūra čia susijusi su pagrindinèmis laiko, būdo (nuosakos) ir kalbinès instancijos kategorijomis. Laiko ir būdo kategorijos svarbios nagrinejjant pasakojamos istorijos ir ją pasakojančio diskurso santykį, o kalbinę instanciją G. Genette’as akcentuoja kalbėdamas tiek apie istorijos ir diskurso, tiek apie diskurso ir pasakojimo akto sąveiką.

(4) Amerikiečių literatūrologès Sidonie Smith ir Julia Watson savo metodinèje studijoje skiria net 60 žanrinių variacijų [15, 253].

(5) $[3,232]$.

(6) $[7,25]$.

(7) $[7,26]$. 
Olandų naratologė Mieke Bal atskiria fabula (atitinka G. Genette’o istorija), tekstą (atitinka G. Genette'o pasakojima, arba diskursq) ir pasakojima (atitinka G. Genetteo pasakojimo aktą) (8). M. Bal šių trijų pasakojimo plotmių atskyrimą laiko teoriniu naratologinès tekstų analizès išeities tašku. Jos teigimu, nors visos pasakojimo plotmès yra susijusios ir priklausomos viena nuo kitos, struktūriškai jas galima nagrinėti kiekvieną atskirai. Tam tikru būdu ir tvarka organizuojami fabulos elementai (ìvykiai, personažai, veiksmo laikas ir vieta) kuria specifini pasakojimą - „itikinantị, jaudinantị, atstumiantị ar estetinị (9). Pagrindiniai pasakojimo aspektai (ịvykių seka, laiko apimtis, charakteriai, fokusuotè), sujungiantys fabulos elementus ir per pasakojantị subjektą (naratorių) kaip mediumą paverčiantys juos ženklais, galiausiai tampa tekstu. Tekstas, pasak M. Bal, gali būti naratyvus, deskriptyvus arba argumentacinis (10). Teksto pobūdis, teoretikès manymu, priklauso nuo intersubjektinių (personažo-charakterio-pasakotojo) santykių.

Taigi R. Barthes’o „naracija“, G. Genette’o „pasakojimas“ (siaurąja prasme) ir M. Bal „tekstas“ iš esmès atitinka diskurso sąvoką, reiškiančią pasakojimo turinio pateikimo būdą arba pasakojimo formą. Straipsnyje diskursas suprantamas kaip ịvykiu visumą iš tam tikros pozicijos perteikiantis pasakojimas. Analizuojami diskurso fragmentai - konkretūs kalbiniai (gramatiniai) pasakojimo požymiai: 1) nurodantys memuarų rašymo tikslus (intenciją) ir pasakotojo ir / arba veikiančio subjekto požiūrị bei santykị su aprašomuoju objektu (fokusuotę), 2) žymintys pasakojimo laiko logikos pažeidimus (anachronijas) arba pasakojimo lygmenų pažeidimus (metalepses), 3) atskleidžiantys vidinès (pasakotojo-veikiančio subjekto) ir išorinès (pasakotojo-adresato) komunikacijos santykị. Diskurso strategijos suvokimas čia iš esmès atitinka Wolfgango Iserio „teksto strategijos“ koncepciją, pagal kurią ji „organizuoja ne tik teksto turini, bet ir šio turinio perteikimo sąlygas“ (11).

Bet koks diskursas, G. Genette’o manymu, suponuoja kalbantijj subjektą (pasakotoją) ir tą, kuriam kalbama (adresatą). Pasakotojas naratologijoje siejamas ne su gramatiniu asmeniu, bet su kalbine instancija. Pagal pasakojamos istorijos atžvilgiu užimamą poziciją, G. Gennette'as skiria heterodiegetinị (kalbantis, pasakojantis, bet pasakojamoje istorijoje nedalyvaujantis kaip veikejas) ir homodiegetinị (ne tik pasakojantis, bet ir pasakojamoje istorijoje veikiantis) pasakotoją. Jo esaties laipsnis pasakojimuose skiriasi (didžiausias jis autodiegetiniame, arba savęs pasakojime, - dienoraščiuose, memuaruose ir pan.) (12). Taigi pasakotojas gali sąmoningai atsiskirti nuo veikiančio subjekto, išlaikydamas atitolintą žvilgsnị i praeities įvykius iš vertinančios pozicijos dabarties taške (stebėtojo vaidmuo), gali susitapatinti su veikiančiu subjektu, pernelyg priartėdamas prie praeities laiko ir nutoldamas nuo išeities taško dabartyje (dalyvio vaidmuo) arba gali išsaugoti dvigubą žiūrą, išlikdamas jungiančiu saitu tarp pasakojamų ịvykių ir jų suvokimo iš dabarties perspektyvos. Pirmaisiais dviem atvejais žiūros taškas yra fiksuotas, o trečiuoju atveju - kintantis.

Pasakotojo esatis ir jo komunikacinis santykis su adresatu atsiskleidžia išoriniame (paties pasakojimo, arba ekstradiegetiniame) pasakojimo lygmenyje, o pasakotojo komunikacinis santykis su veikiančiu subjektu - vidiniame (pasakojamos istorijos, arba intradiegetiniame) pasakojimo lygmenyje. Pasakotojo (autoriaus) išreikštumo laipsnis memuariniuose pasakojimuose yra skirtingas (priklausantis nuo pasakojimo intencionalumo ir distancijos), jo
(8) $[2,5]$.
(9) $[2,7]$.
(10) $[2,8]$.
(11) $[10,53]$.
(12) $[7,245]$. 
kalbejjimo trajektoriją žymi specifiniai naraciniai ženklai (autobiografiniai elementai, pastabos, svarstymai, komentarai, vertinimai, savianalizès intarpai, aktyvus ir tiesioginis komunikavimas su adresatu). Pasakotojo (autoriaus) naraciniais ženklais galima laikyti ir intertekstinius elementus, kompozicinius sprendimus, kalbinès raiškos ypatumus. Todèl svarbu atkreipti dėmesį ne tik ị ịvairius nesiužetinius komponentus (ịterptines konstrukcijas), užpildančius erdves tarp pasakojimo branduolių, bet ir ị dialogų modeliavimo principus, nukrypimus nuo pagrindinès pasakojimo linijos, pasikartojančius leitmotyvus ir pan. Pavyzdžiui, dialogai memuariniame pasakojime gali atlikti skirtingas funkcijas, t. y. jie gali veikti kaip konkrečios epochos atspindèjimo būdas (per kalbejjimo manierą ir vartoseną), kaip papildomas informacijos šaltinis, kaip charakterizavimo priemonè. Dialogai gali būti tiesioginiai (tarp pasakojime veikiančių subjektų), metafiziniai (tarp pasakotojo ir esamų ar net nesamų personažų), išoriniai (tarp pasakotojo ir skaitytojo). Monologai memuariniame pasakojime taip pat funkcionuoja skirtingai: autoriaus (pasakotojo) monologai skirti išvadoms, apmąstymams ar emociniam fonui sukurti, o veikiančių subjektų monologai atlieka charakterizavimo funkciją. İvairūs intertekstiniai elementai (citatos, dokumentų, laiškų fragmentai, perpasakojimai ir pan.) išplečia memuarinio pasakojimo informacinį, emocinị lauką, kontekstą, laiko ribas. Jie gali atlikti autoriaus pozicijos sustiprinimo, patvirtinimo funkciją, taip pat igauti konkretizuojančios, papildančios, argumentuojančios, iliustruojančios ar net provokuojančios detalès vaidmenị. Intarpai iš dokumentų, laiškų, archyvinių leidinių paprastai sustiprina autentiškumo, objektyvumo ịspūdị, o literatūros kūrinių citatos kuria emocinị pasakojimo foną, pratęsia, papildo pasakotojo kalbą.

Kaip pabrežzia G. Genette'as, pasakotojas atlieka ne vien pasakojimo (arba naratyvinę) funkciją, kuri yra pagrindinè ir privaloma, bet ir kitas - valdymo, komunikacine, liudijimo, ideologine - funkcijas, kurias teoretikas laiko ekstranaratyvinèmis (13). Valdymo funkcija susijusi su metadiskursu, t. y. pasakotojas paaiškina pasakojimo struktūrą, tvarką, jo atsiradimo aplinkybes ir pan. Komunikacinė funkcija - kai pasakotojas tiesiogiai kreipiasi ị adresatą, siekdamas išlaikyti ryši arba padaryti poveikį. Kai pasakotojas patvirtina pasakojamos istorijos autentiškumą, nurodo informacijos šaltinius, atskleidžia asmeninị santykị su pasakojamais ivvykiais, išryškèja liudijimo funkcija. Ideologinė funkcija susijusi su pasakotojo vertinimu, didaktinèmis išvadomis ir komentarais.

Autoriaus ịvaizdis memuariniame pasakojime realizuojamas per pasakotojo ir veikiančio subjekto figūras. Kiekvienas jų atveria vis kitokị santyki su savimi, aplinka ir laiku, kol galiausiai šie skirtingi žiūros rakursai susijungia ị vientisą pasaulèvoką. Taip atsiminimuose per konkretų asmenị atsiskleidžia apibendrintas istorinėje epochoje ir kultūrinėje terpėje veikiančio žmogaus portretas.

I skirtingas memuarinių tekstų diskurso strategijas dėmesị atkreipęs rusų literatūrologas Ilonas Fraimanas (14) pabrèžia, kad išskirtinè memuarų ypatybè - objektyvios tikrovès ir subjektyvios patirties susidūrimas - leidžia ị šị žanrą pažvelgti ne tik kaip ị istorinị šaltinị, bet ir kaip ị literatūros objektą. Pasak mokslininko, skirtingas istorijos suvokimas lemia memuarinio pasakojimo strategijų pasirinkimą ir ịvairovę. Remiantis I. Fraimano pasiūlyta memuaristikos tipologija, pagal dominuojančius pasakojimo kūrimo principus galima išskirti tris pagrindinius memuarinio pasakojimo strategijų tipus (15). Deskriptyvaus pasakojimo strategija

(13) $[7,255-257]$.

(14) $[6,346-361]$.

(15) Olandų kritikè Mieke Bal taip pat išskiria tris beveik analogiškus tekstų (arba diskursų) tipus: deskriptyvu, naratyvu ir argumentacini $[2,8]$. 
paprastai būdinga objektyvaus liudijimo įspūdị kuriantiems istoriniams-kultūriniams memuarams (16). Čia žvilgsnis sutelkiamas ne tiek ị pasakotoją, kiek ị pasakojimo objektą (rekonstruojamus praeities ịvykius tam tikrame istoriniame-kultūriniame kontekste), aprašant praeities laiką išlaikoma vertinanti, apibendrinanti pasakotojo pozicija iš dabarties perspektyvos. Naratyvinio pasakojimo strategijai, atvirkščiai, būdinga i pasakotoją ir jo tapatumo formavimąsi tam tikromis aplinkybėmis ir sąlygomis nukreipta žiūros trajektorija (17). Čia itin ryški subjektyvumo, individualios patirties dominantè. Pasakotojui susitapatinus su veikiančiu subjektu, priartejjama prie rekonstruojamo praeities laiko ir atitolstama nuo išeities pozicijos dabarties laike. Tikslingo arba nukreipto ị tiesioginę skaitytojo reakcija pasakojimo strategija dažniausiai susijusi su autoriaus reputacijos ar naujo tapatumo kūrimu ir įtvirtinimu, siekiant pateisinti praeityje padarytus veiksmus, pasirinkimus ar sprendimus (tokio pobūdžio pasakojimuose dažnai nevengiama ir įvairių praeities falsifikavimo būdų), arba atstatyti tam tikrą istorinį teisingumą, paliudijant ir išsaugant kolektyvinejje atmintyje trauminę (karo, tremties, holokausto) praeities patirtị (18). Čia svarbesnis dabarties laikas, kuris tarsi liudija skaitytojui „tikrąjį pasakotojo tapatumą čia ir dabar, iškeldamas ji virš "netikrojo“, vienokių ar kitokių nepalankių aplinkybių suformuoto tapatumo ten ir tada. Taip pat svarbu ir tai, kad viename memuariniame tekste gali išryškèti kelios skirtingos diskurso strategijos. Kiekvienu atveju, jei įmanoma, reikètų nustatyti dominuojančią poziciją.

Šio straipsnio tikslas - pasirinktus memuarinius tekstus išanalizuoti pasakojimo formos aspektu ir išryškinti pagrindinius analizuojamų memuarinių pasakojimų diskurso komponentus bei jų sąveiką. Analizei pasirinkti keturių lietuvių rašytojų - teatrologių Gražinos Mareckaitès ir Audronės Girdzijauskaitès, žurnalistès, vertèjos Silvijos LomsargytèsPukienès ir poetès Juditos Vaičiūnaitès - jau nepriklausomoje Lietuvoje parašyti ir publikuoti memuariniai tekstai. Renkantis autorius atsižvelgta ị tai, kad literatūriniai (rašytojų, kultūros asmenybių) memuarai paprastai pasižymi didesne diskursyvinès raiškos ịvairove.

\section{NOSTALGIJA: TARP ATMINTIES IR VAIZDUOTĖS}

Nostalgija (lot. nostos - grižimas namo, algia - ilgesys), kaip savitas atminties aspektas, dichotomiškai susijusi, viena vertus, su ilgesiu ir noru prisiminti, sugrąžinti, atkurti tai, kas prarasta, kita vertus, su skausmu, kad to padaryti neįmanoma. Memuarinio teksto pasakotojas, siekdamas rekonstruoti praeities patirtis ir įprasminti jas dabartyje, paprastai neišvengia laiko distancijos sukurto daugiau ar mažiau nostalginio prisiminimų fono (išskyrus, žinoma, tam tikras anomalines tremties, lagerių, kalejjimų patirtis). Vis dẻlto galima išskirti tam tikrą grupę memuarų, kuriuose nostalginis pasakojimo pradas yra itin ryškus, iš esmés veikiantis diskursyvinę jo raišką. Kitaip nei deskriptyviuose istorinio-kultūrinio tipo memuariniuose pasakojimuose, nostalginiuose memuaruose išryškejja naratyvinio pasakojimo strategija (naratyvo ašimi čia tampa pasakotojas ir jo individualios patirties refleksijos). Galima teigti, kad deskriptyviame diskurse, per pasakotojo aš žvilgsnị sutelkiant ị pasakojamą objektą (ịvykius ir juos lèmusias socialines, istorines, kultūrines sąlygas), kuriamas „didysis pasakojimas“. Tuo tarpu naratyvinis diskursas, kuriame žvilgsnis nukreiptas ị tam tikrų sąlygų veikiamą pasakotojo

(16) Tokio tipo pasakojimais galima būtų laikyti Merkelio Račkausko, Julijos Biliūnienės-Matjošaitienės, Gedimino Jokūbonio atsiminimus.

(17) Šiame straipsnyje bus analizuojami naratyvinio tipo nostalginiai Juditos Vaičiūnaitès, Audronès Girdzijauskaitès, Silvijos Lomsargytès-Pukienès, Gražinos Mareckaitès memuarai.

(18) İ tiesioginę skaitytojo reakciją paprastai nukreipti buvusių politinių veikèjų atsiminimai arba tremtį, holokaustą, įkalinimą išgyvenusių asmenų memuarai. 


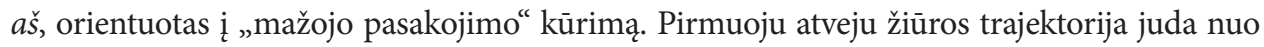
individualios patirties refleksijų link santykinai objektyvios kolektyvinès atminties rekonstravimo (iš vidaus ị išorę), antruoju - nuo istorinio-kultūrinio fono link asociatyvių, su emocijomis ir subjektyviu vertinimu susijusių prisiminimų (iš išorès ị vidų).

Siekiant išryškinti subjekto santykị su pasakojimo objektu (nostalginiame diskurse ji pagrịstai galima vadinti prarastuoju objektu), straipsnyje bus remiamasi rusų kilmès literatūrologès Svetlanos Boym teorinėmis įžvalgomis. Savo studijoje The Future of Nostalgia (Nostalgijos ateitis, 2001) ji nostalgiją apibūdina kaip savotišką utopinę dimensiją, kur subjekto žvilgsnis nukreiptas ne ị ateitị ir net ne ị praeitị, o kažkur šalia - ilgimasi to, kas nebeegzistuoja arba niekada neegzistavo (19). Glaudžiai susijusi ne tik su atmintimi, bet ir su vaizduote, nostalgija "reikalauja“ išlaikyti distanciją tarp subjekto ir jo prarastojo objekto, priešingu atveju, realaus ir susikurto vaizdinio neatitikimas tampa neišvengiamas (tokia tikrovès ir lūkesčio disociacija atsiskleidžia ir toliau nagrinejjamuose memuariniuose tekstuose). Kartais nuo objekto atsitraukti (išvykti iš tèvynès, palikti gimtuosius namus) siekiama ir laisva subjekto valia, taip sukuriamos sąlygos romantizuotai ir estetizuotai nostalgijai atsirasti. Kita vertus, ilgą laiką reflektuojant per atstumą, iškyla grèsmė tikrąji ilgesio objektą pakeisti iliuziniu, arba, kaip ịvardija S. Boym, fantominiu (angl. phantom) objektu (20).

Nors paprastai nostalgija siejama su prarastos erdvės (namų, tèvynės, miesto ar gamtos) ilgesiu, tačiau, S. Boym teigimu, iš tiesų ilgimasi kito (negrižžtamai praejusio) laiko - tradicijų, gyvenimo tvarkos, bendruomeniškumo, socialinès ir kultūrinès atmosferos. Ypač stiprus vaikystės ilgesys, kuris pasakojimuose tradiciškai metaforizuojamas Prarastojo Rojaus ịvaizdžiu. Nostalgija iš esmès gimsta tokių vaizdinių kaip namai - svetima erdvé, praeitis - dabartis, svajonès - kasdienybe sankirtoje. Kitaip nei melancholija, kuri apsiriboja individualia sąmone, nostalgija, pasak S. Boym, susijusi su santykiais tarp asmeninès ir kolektyvinès biografijos, tarp individualios ir kolektyvinès atminties (21).

Pagal subjekto santyki su prarastuoju objektu S. Boym skiria dvi nostalgijos rūšis: atkuriančiają (angl. restorative) ir refleksyviaja (angl. reflective). Atkuriančiąją nostalgiją mokslininkè sieja su kolektyvine atmintimi ir kultūra, o refleksyviąją - su individualia fragmentuota atmintimi. Atkuriančioji nostalgija, pasak jos, susitelkia i prarasto objekto rekonstravimą (savotišką praeities atkūrimą ir išsaugojimą mito ar simbolio pavidalu) atmintyje. Praeitis čia igyja vertę ir prasmę dabartyje kaip užfiksuota, išsaugota ir subendrinta kolektyvinèje atmintyje. Tuo tarpu refleksyvioji nostalgija linkusi ị sąstingi ties iliuziniu prarastojo objekto vaizdiniu, ị kitos vietos ar kito laiko skausmingą ilgesị ir meditaciją, joje paprastai išryškejja gedejimo ir melancholijos momentai. Pastarasis santykis yra nestabilus, fragmentuotas, susijęs su subjekto emocijomis ir vaizduote. Vis dèlto S. Boym atkreipia demesị, kad ir tokiu atveju subjekto prisimenamos asmeninès patirtys neišvengiamai daugiau ar mažiau susijusios su istoriniu ir kultūriniu jų fonu. Siekiant pasidalyti savo nostalgija ir taip tarsi ịtvirtinti jos esaties pagrịstumą, paprastai komunikuojama su kolektyvine atmintimi, kitaip tariant, subjektas, skausmingai ilgèdamasis to, kas prarasta, kuria įsivaizduojamą dialogą su išsibarsčiusiais panašaus likimo žmonėmis, ieškodamas bendrų patirčių ir išgyvenimų (22).
(19) $[4,14]$
(20) $[4,16]$.
(21) $[4,16]$.
(22) $[4,52]$. 


\section{NARATYVINĖ NOSTALGINIO DISKURSO STRATEGIJA}

Judita Vaičiūnaitė. Mabre viešbutis: memuarinė proza (2009) (23)

„Tik muilo burbulai, vaivorykštinès jų spalvos dar gyvos širdy..."

J. Vaičiūnaitė

J. Vaičiūnaitès atsiminimuose (paantraštejje pristatomuose gana abstrakčiai - kaip memuarinè proza, nors, matyt, tikslesnis ịvardijimas būtų memuarinès novelès) (24) reflektuojamos praeities patirtys ir būsenos, susijusios tiek su pasakojamų ịvykių erdvės kaita, tiek su laiko tèkmės refleksijomis: pirmoji knygos dalis skiriama gimtajam Kaunui ir jame praejusiems vaikystės metams, antroji - autorés jaunystės miestui Vilniui. Nostalgija čia itin ryški ir stipriai veikianti diskursyvinę pasakojimo raišką. Pasakotoja, „laužydama“ tradiciniams memuarams būdingą formą, nenurodo atsiminimų rašymo tikslo ar intencijos, nęivesdina adresato ị pasakojimą ir neformuoja jokių išankstinių jo skaitymo lūkesčių, nepateikia konkrečios savo pozicijos pasakojamų ivykių atžvilgiu, taip atsisakydama su metadiskursu susijusios valdymo funkcijos (25). Ji pasakoja tarsi „pati sau“, vengdama tiesioginio kontakto su pasakojimo adresatu (tai rodo ir komunikacinès pasakotojo funkcijos (26) nebuvimą), vedama praeities nostalgijos atgaivintų asociatyvių, subjektyvių, emocijomis nuspalvintų prisiminimul.

Pasakojamos istorijos erdvés ir laiko (prieškarinis Kaunas - pokario Vilnius) ribos, sudarančios pirminius siužetinio pasakojimo rèmus, čia išplečiamos paraleliai kuriant mitologizuotą, vizijomis ir sapnais apipintą paties pasakojimo (diskurso) erdvélaikị. Veikiama laiko distancijos ir nostalgiško pasakotojos žvilgsnio, dabarties pozicijoje rekonstruojama praeities tikrove deformuojasi, kinta, igauna naujus pavidalus. Tuo pat metu išryškejjantis to, kas büta, ir to, kas esama, neatitikimas susijęs su trūkumo, praradimo ir neužpildomos tuštumos jausena. Tarsi kompensuodama pilnatvès nesatị ir negalimumą dabarties tikrovèje, pasakotojos vaizduotė kuria menamą, iliuzinị miestą, tokiu būdu tarsi igalindama veikiančią subjektę čia ir dabar vél regèti tai, kas neregima:

Kada tik užklystu j̣ Gedimino gatvę prie Žemaičiu laiptu, dursteli širdị nuo pasikeitusio vaizdo. Iš rūku kaip gyvas išnyra žalias medinis namas. Ir žydi kaštonai, kuriu seniai nebèra (27).

Išoriniame (ekstradiegetiniame) pasakojimo lygmenyje išryškejja nuolat pasikartojantys prisiminimo kaip vaizdinio, miražo, sapno ir užmaršties kaip miglos, rūko motyvai. Rekonstruojant dabartyje jau nebeegzistuojančius objektus, esama tikrovè ir iliuzinè regimybè susitinka, kryžiuojasi, persipina, tačiau nepanaikina viena kitos. Sapno metafora, pasak W. Iserio, pasakojime iškelia kartojimo ir atminties susipynimo aspektą: čia du pasauliai nekonfrontuoja, o tarpusavyje susluoksniuojami, ir dèl to atsidengia tai, kas kiekviename jų užgniaužta (28). Sapną J. Vaičiūnaites pasakojime galima interpretuoti kaip su kita (nebeegzistuojančia) tikrove siejančią patirtị, savotišką tikrovejs ir regimybės priešpriešos modelį:

(23) 1996 m. išleista Juditos Vaičiūnaitės atsiminimų knyga Vaikystès veidrody, skirta Kaune praejusiems vaikystès metams. 2009 m. pasirodęs Mabre viešbutis - tai pačios autorès suplanuotas pirmosios knygos tęsinys, kuriame pakartotinai publikuojama ir papildyta pirmoji memuarų dalis, ir jaunystès laikotarpi iki dukters gimimo apimantys tekstai.

(24) [16].

(25) $[7,255]$.

(26) $[7,255]$.

(27) $[16,60]$.

(28) $[9,58]$. 
O gal ta moteris su mergyte ir nenakvojo, gal aš tik sapnavau. Tokie tiršti šilti garai, gal tai rūkas, o gal tik sapno migla. Kas dabar pasakys, kai tiek metu praèjo (29).

Praeities vaizdiniai J. Vaičiūnaitès atsiminimuose rekonstruojami selektyviai, sekant nostalgijos prikeliamomis asociacijomis ir emocijomis. Pasakotojos sąmonè, iš naujo patirdama intensyvius praeities išgyvenimus, pirmiausia grịžta ị savo gyvenimo ištakas, ị pradžios laiką, kai užsimezgè pirminis jos santykis su išoriniu pasauliu. Ankstyvosios vaikystès prisiminimai, kurių atmintis iš esmès nepajègi autentiškai rekonstruoti, pasakojime kuriami per santyki su savotiškais tarpininkais tarp praeities ir pasakotojos atminties tapusiais kitais veikiančiais subjektais (tèvais, vyresne seserimi, dède):

Štai tame name šviesią, dar prieškario vasaros diena parnešta iš ligoninès ir pradejjau savo gyvenimo kelionę. <...> „Tikra Judita“, - pasake pirmąkart mane pamatęs tèvas, o varda jau buvo išrinkęs Petras Vaičiūnas. <...> Pasilenkę tèvų veidai ir dvimetè susijaudinus sesute $\langle\ldots>$, audringai, su tokia meile mane sutikusi (30).

Vis labiau mažejant distancijai tarp pasakotojos ir veikiančios subjektės, prisimenamų artimų žmonių, gimtųjų namų ir kasdienès aplinkos detalès pamažu igauna apčiuopiamus kontūrus, atmintyje vẻl tarsi dabar „atsitinka“ svarbiausi gyvenimo ịvykiai. Prisiminimų asociatyvumas, kylantis iš kažkada regètų vaizdų fragmentų, atgyjančių garsų, kvapų, skonio ir lytėjimo pojūčių, stiprių emocinių ìspūdžių, ypač patirtų vaikysteje, pasakojime atskleidžiamas kontrasto principu - išryškinami laimès ir skausmo ženklai („Ir kapo duobẻ atsivèrè beveik ten, kur mes kažkada rinkdavom šilagèles.") (31).

Sutampanti pasakotojos ir veikiančios subjektès žiūros trajektorija išryškina asmenišką, emocinį pasakotojos santykị su pasakojamais praeities ịvykiais. Poetinių priemonių ir vaizdinių gausa tik patvirtina, kad pasakojime svarbu ne tiek realistiškai atkurti praeitị, kiek perteikti išgyvenamą emociją ar patiriamą būseną. Lyriškas pasakojimas „sutirštinamas“ refleksyvios meditacijos, nuspalvintos melancholiško skepsio ir tarsi išankstinio gedejjimo, nulemto autorès žinojimo, kas bus, ịvyks vèliau.

J. Vaičiūnaitès pasakojime gausu netiesioginių autorès ženklų: intertekstinių detalių, simbolių, metaforų. Kauno Žaliakalnio sodai čia - tradicinè aliuzija ị Prarastąji Rojaus sodą, kuris iškyla kaip šviesus vaikysteje išgyventų patirčių ịvaizdis. Jo centre - obelis („saulès medis aukso obuoliais“) - Pažinimo medis, simbolizuojantis nesugrąžinamai prarastą idilišką vaikystės erdvėlaikị. Ypatinga reikšmė pasakojime taip pat teikiama kaštonui (šalia namų auga kaštonai, kaštonų pilnos kišenès, moteris kaštoniniais plaukais, Kaštonų gatvė), kuris iškyla tarsi Pasaulio medžio, jungiančio gyvųjų ir mirusiųjų pasaulius, atitikmuo, ženklinantis gamtos ir žmogaus būties cikliškumą:

Mano vaikystès metais Gedimino gatvès gale augo kaštonai - svaigiom, stačiom baltom su rožiniais taškeliais kekèm žydèdavo pavasarị, vasara šlamédavo žaliom plunksninèm vèduoklem - dideliais lapais, rudeni iš dygliuoto kevalo išlukštendavau tamsiai ruda blizgantį, tokị gražu vaisiu (32).

Vaikystès pasaulis J. Vaičiūnaitès pasakojime atkuriamas per asociatyviai iškylančius stebuklinès pasakos motyvus (dažnas karalaitės ir pilies vaizdinys, vaikystės svajonių simbolis, iškylantis ịvairiuose intertekstiniuose lygmenyse - tapybos darbe, muzikos kūrinyje, pačios autorès eilèraštyje), taip pat siejamas su aukso spalva, švytėjimu, saule, gyvo vandens

(29) $[16,56]$.

(30) $[16,7]$.

(31) $[16,62]$.

(32) $[16,11]$. 
čiurlenimu fontanuose („Šito fontano vanduo žybčiojo saulèj, jo baseine plaukiojo auksinès žuvytès, o vidury iš uolos išskèlè versmę bronzinis barzdotas nykštukas. " (33)) ir tuo pat metu su mirtimi, nykimu, praradimais (itterpiama tiesioginè intertekstinė nuoroda į Hoffmanno pasaką Smèlio žmogus: „Smèlio žmogiukas, vakarais atnešdavęs mums sapną, užbèrè smèliu sesers akis. Giminès albumas apaugo žole.“ (34)). Atmintyje atgyjantis milžiniškų ir vaivorykštinių muilo burbulų vaizdinys metaforiškai nurodo pasakojime kuriamo vaikystès pasaulio iliuziškumą ir trapumą.

Tarpinę pasakotojos-subjektės būseną tarp realaus (pasakojimo) ir menamo (pasakojamų ivvykių) laiko, tarp esamos ir buvusios tikrovès, taip pat ir savotišką perèjimą iš vieno pasaulio ị kitą pasakojime žymi pasikartojantys laiptų, durų, vartu ženklai (Žemaičių, Dzūkų, Kauko, Aušros Tako laiptai netoliese gimtojo namo; laiptais aukštyn ị dangaus begalybę, ị pasaką kopianti karalaite iš Kazio Šimonio paveikslo, kabojusio salone; dvivėrès durys, atsiveriančios i tèvo kabinetą; užrakinti kiemo vartai). Ryšį tarp šiapus ir anapus, gyvụjų ir mirusiųjų simbolizuoja dažnai pasikartojantis paukščio leitmotyvas (kaip likimo žymè, nelaimès ženklas - mirusios krikšto motinos juodi lyg kregždès sparnai suaugę antakiai nuotraukoje ir greta pačios autorès tokie pat antakiai, atsispindintys veidrodyje; atsitiktinė praeivė paslaptingu vardu Kira, kurios „,vardas plakè paukščio sparnais“; dainavimo pedagogè, iš kurios kambario sklinda lyg paukščio čiulbesys; pasivaikščiojimai griuvėsių gatve, kur ant grèsmingai stūksančios sienos , „i dangų kyla trys granitiniai grifai“).

Moteriškojo tapatumo formavimosi procesas, moteriškosios lemties ženklai (35) - pagrindinè pasakojamos istorijos tematinè linija - J. Vaičiūnaitès pasakojime atskleidžiami per šeimos moterų "gyvenimo-žaidimo“ ritualo perèmimą iš kartos ị kartą. İvedami šio amžino žaidimo atributus žymintys kortų, sūpynių, karuseles, kaleidoskopo leitmotyvai (pasikartojantys ir autorès poezijoje) nusako subjektès santykị su laiku, pačia savimi, artimiausiais žmonèmis ir supančiu pasauliu. Kaleidoskopas - gražiausias vaikystès žaislas, suskaldantis pasaulị $\mathfrak{i}$ daugybę spalvotų šukių. Karusele - amžinai besisukantis, gyvenimą ir žmones keičiantis laiko ratas $(„<\ldots>$ karuselès žavesį ir siaubą Tu žinai ne blogiau už mane..." (36)). Sūpuoklès simbolizuoja tarpinę būseną tarp dangaus ir žemès, gyvenimo ir mirties, buvimo čia ir anapus (žinia apie pažịstamo berniuko mirtị subjektei sukelia svaiginantị supimosi potyrị). Užburianti kortų tvarka, simetrija, paslaptinga hierarchija ịkūnija pačią lemtị. Aprašomas pasikartojantis motinos, vèliau dukros kortų dèliojimo („gyvenimo-žaidimo“) ritualinis veiksmas, perkeliantis pasakojamus ịvykius ị metafizinę plotmę:

Ak tie karaliai, valetai, tas žavus jokeris. Jie šoko mano sapnuose, dalyvavo keistoj pantomimoj. Kaip trauke laimingas širdžiu pasaulis, kaip gaude ausyse raudoni bügnai, baugino kryžiai, primindami kapines, paslaptingai šlamèjo pikai, brandindami juoda vyną. <...> Dar girdžiu ją kuždant: kas buvo? kas bus? prie ko paliksi? su kuo nusiraminsi? kas tave nustebins? kas tau širdi nuramins? kas tavo laimei? kas tau ant širdies? (37).

Emocinis praeities išgyvenimų ir patirtų būsenų fonas J. Vaičiūnaitès pasakojime kuriamas pasitelkus spalvų žaismą. Greta švytinčios aukso spalvos, ženklinančios idilišką, kupiną gyvybės ir dieviškumo vaikystės rojų, atsiranda pasikartojantis žydros spalvos leitmotyvas (žydros sesučių ir mamos suknelès, žydras kaspinas, žydras meškinas, žibuoklès, po stiklu

(33) $[16,13]$.

(34) $[16,55]$.

(35) Apie moteriškumą J. Vaičiūnaitės kūryboje žr. [5, 504].

(36) $[16,128]$.

(37) $[16,66]$. 
žydri atogrąžų drugiai). Ši spalva, tradiciškai simbolizuojanti viltị, tyrumą, dangaus karalystę, pasakojime iggauna liūdesio, ilgesio, net mirties išraišką (tẻvo dovanojamos žibuoklių puokštelès, žibuoklès sesers karste nurodo meilę ir mirtị, nuolat esančias greta). Dažnas baltos spalvos motyvas (balta vaikiška lovelè, balti dobilai, chrizantemų sniegas, baltas, vaistais kvepiantis chalatas, balta nosine, skarelè, blykštantis mamos veidas, baltas angelas kapinėse, baltas popieriaus lapas), reiškiantis tyrumą, nekaltumą, tikejjimą, tuo pat metu ženklina ir tuštumą, netektị, trūkumą. Laikas po tèvo mirties pasakojime pažymimas juoda ir raudona (gedulo ir meilès) spalvomis (mama dažo savo raudoną megztuką juodai, juodas smuiko dèklas išmuštas raudonu aksomu, juodi suolai, juodi raiščiai ant rankovių, raudonai dažytos moters lūpos bespalveje nuotraukoje).

Sąmoningai autorès parenkamų ir derinamų tarpusavyje spalvų reikšmės kuria bendrą vientisą pasakojimo spalvinị foną, nurodantị kintančią dvasinę subjektès būseną, dažnai ženklinamą nostalgijos, liūdesio, tuštumos ir netekties. Pasakotoja, susitapatindama su veikiančia subjekte, vis labiau priarteja prie reflektuojamo praeities ịvykių laiko ir "pameta“ pasakojimo išeities poziciją dabartyje, taip pereidama iš išorinio (ekstradiegetinio) pasakojimo lygmens ị vidinị (intradiegetinị):

Mano garlaivis dar vis plaukia. Jeigu labai šalta ar lyja, slepiuosi atminty jo skurdžioj kietoj kajutèj, ten irgi savaip gera, ypač jei esi ne viena, o tave apglèbus sava miela stipri ranka (38).

Elegiška J. Vaičiūnaitès nostalgija, nors intertekstiniame lygmenyje ir projektuojama i kūrybinę plotmę, atkuriant praeitị mito ar simbolio pavidalu (39), memuariniame pasakojime išlieka refleksyvi ir meditacinė, sukelianti pasakotojos-subjektès vidinių būsenų ir išorinès būties disociacijas.

\section{Audronė Girdzijauskaitė. Atminties salos (2008)}

"Nuskendęs miestas, kuris yra ir kurio nebėra..."

A. Girdzijauskaitè

A. Girdzijauskaitès memuarų knyga Atminties salos (2008) - tai subtilus, skaidrus, preciziškai atrinktų detalių ir ịspūdžių prisodrintas pasakojimas apie autorès vaikystès ir jaunystès miestus (prieškarinị Kauną, Permę ir Maskvą karo metais, pokario Palangą ir Vilnių), jų žmones, aplinką, socialinę ir kultūrinę atmosferą. Tiek paties pasakojimo (diskurso) laikas, tiek pasakojamų ịvykių (istorijos) laikas čia juda ne chronologine linijine seka, bet yra pavaldus asociatyviai pasakotojos atminčiai, vis iš naujo (taip pat ir jau kitaip) sugrąžinančiai tam tikrus vaizdinius, patirtis, būsenas, išgyvenimus. Kinematografiškai rekonstruojant praeities prisiminimų fragmentus, nostalgija ir santykis su prarastuoju objektu atsiskleidžia keliais rakursais. Visų pirma - kaip „pasakojimas pasakojime“, kai tėvų ilgesys tarsi rezonuoja pasakotojos sąmonèje:

O mano prisiminimai subjektyvūs ir ryškiausia juose turètu būti ypatinga ilgesio nuotaika, ne tiek mano, kiek mano tèvu nuotaika. Jie buvo liūdni, nes suvokè, kad tai, ka norejjo anasyk mums parodyti - to jau nebèra. Tarsi nušluota (40).

Pasakotojai grịžtant ị vaikystės laiką, praleistą Permèje, vèliau Maskvoje, kur Girdzijauskų šeima buvo laikinai apsistojusi karo metu, iš padrikų prisiminimų visumos (autorei tuo metu tebuvo treji) išgriebiamos tèvų pasakojimų („lyg pasakų“) nuotrupos apie prieškarinę Lietuvą, ten paliktus namus ir artimus žmones. Nostalgini foną čia kuria ne tik perpasakojamos

(38) $[16,107]$.

(39) Apie praeities mitologinimą J. Vaičiūnaitès kūryboje žr. [14].

(40) $[8,129]$. 
istorijos, bet ir fotografiškai užfiksuoti atmintị saugoję daiktai (sesers Dalios, per bombardavimus negalejusios išvykti kartu ir likusios pas senelius Raseiniuose, portretas, „kuriame ji pasisukusi profiliu liūdnai žiūrèjo ị tolị ir kažkuo priminé Šimonio madonas“ (41)). Kaip tokios „perimtos" nostalgijos apraiška pasakojime iškyla ir ị vaikišką sąmonę giliai ịstrigęs tèvo tarsi perduotas (ir ateityje jau pačios subjektės sąmoningai kartojamas) savotiškas ritualinis veiksmas, kai besibaigiant karui grižus ị Lietuvą ir lèktuvui nusileidus išsvajoto, išsapnuoto Vilniaus oro uoste, jis sublogavusią dukrą gydè paguldydamas kniūbsčią ant žemès:

Kvépuok giliai. Nuo savos žemés kvapo tuoj visi pykinimai praeis (42).

Pasakojamų ịvykių suvokimo šaltinis, arba fokusuotė (43), Girdzijauskaitès pasakojime nèra fiksuota. Kalbejjimą iš viską žinančios pasakotojos perspektyvos (nulinis fokusavimas) keičia kalbejjimas iš pagrindinès subjektès (ar kitų pasakojime veikiančių subjektų) perspektyvos (vidinis fokusavimas). Pavyzdžiui, iš subjektès pozicijos parodoma, kaip tèvų nostalgijos suformuotas romantinis, estetizuotas tèvynès vaizdinys grịžus ị Lietuvą stipriai disonuoja su regima tikrove. Išnykus distancijai, realus objektas nepateisina išankstinių subjektès lūkesčių, per laiką sukūrusių jos sąmonèje savotišką idealios tèvynès ir namų erdvès projektą:

Važiuodami duobètomis senamiesčio gatvèmis, matèm vien griuvèsius su bauginančiomis langų kiaurymèmis. <...> Tai kurgi tas pasakiškas baltu bokštu miestas? Kurgi tos pilys, apie kurias tiek pasakojo Mama? (44).

Kiek kitu rakursu atsikleidžia pačios pasakotojos tiesiogiai patiriama nostalgija. Ji susijusi su kito (praeities) laiko ilgesiu - vaikystes, kaip ontologinio saugumo pagrindo, ir praeities kultūros atmosferos, apie kurią byloja tik nuotraukos, vietos, daiktai ir atmintis. Pasakotojos atmintyje praeities pasaulis iškyla kaip nostalgijos ir laiko transformuotas vaizdinys, kuris tèra menamas ir pasakojimo dabarties tikroveje nebeegzistuojantis:

Taip būna, kai žiūri per vandenị i nuskendusị daiktą: tie patys, tik banguojantys, kontūrai, lyg ir tos pačios formos bei spalvos, bet viskas kitaip, blankiau. Atrodydavo, kad vaikštau briauna, kuri skiria praeiti nuo dabarties, jausdama abi puses ir skaudžiai ilgédamasi to, kas buvo (45).

Vaikystès ilgesys A. Girdzijauskaitės pasakojime - tai konstruojamas asociatyvus patirtų pojūčių, išgyventų akimirkų ir būsenų koliažas, surinktas iš skirtingų praeities miestų, žmonių ir kasdienybės detalių. Sąsajos su prarastu ontologiniu saugumu ir jau minètu Rojaus sodo ịvaizdžiu išryškèja prisimenant tuometinị Kauną:

Atèjus iš miesto laiptais, prieidavai vartelius su stilizuota tulpe; kai sunkūs varteliai užsitrenkdavo, čia jauteisi saugus, lyg kokiam rojaus sode... (46).

Gimtasis miestas, pirmiausia pažintas per motinos atmintị (iš jos saugomų atviru$\mathrm{kų}$, nuotraukų, pasakojimų), pačios pasakotojos-subjektès prisiminimuose atgaivinamas kartu su ją supusių žmonių ir aplinkos vaizdais. Iki šių dienų saugomi daiktai („krištolo bombonjerè ir balta vaza gèlèms iš prieškarinių Antrosios Mamytès sankaupų“ (47), tos pačios Mamytės sukurta lèlè) pasakojime tampa laimingos ir skaidrios praeities liudytojais. Mažylių, Milašų, Vabalevičių šeimos (su jomis tuo metu gana artimai bičiuliavosi autorès

(41) $[8,31]$.

(42) $[8,33]$.

(43) $[7,189]$.

(44) $[8,34-35]$.

(45) $[8,131]$.

(46) $[8,141]$.

(47) Antraja Mamyte A. Girdzijauskaitè vadina Feliciją Vabalevičienę, neoficialią savo krikštamotę $[8,148]$. 
tėvai Kaune), o ypač jų namų aplinka A. Girdzijauskaitės prisiminimuose iškyla kaip simbolizuojantys emocinị komfortą (jaukumą, ramybę, tvarką) ir tuo pat metu ịkūnijantys aukštą prieškario Lietuvos buities kultūrą bei tuometinę buržuazinès inteligentijos gyvenimo gerovę (riešutmedžio baldai, krištolas ir porcelianas, vašku ịtrinto parketo kvapas ir gèlès, elegancijos ir subtilaus skonio ženklas). Vaikystès Kauno dvasia (kuri savo prašmatnumu pasakotojos priešinama pokario Vilniaus purvui ir skurdui - „Vilniuje tokių dalykų neteko matyti, Vilniuje viskas kitaip“ (48)) pasakojime "prikeliama“ per tulpés įvaizdi (atsimenamas stilizuotos tulpès ornamentas ant vartelių, „Tulpès“ kringelio, kurị subjektè visuomet gaudavusi dovanų nuo Antrosios Mamytės per gimtadienius, nepamirštamas skonis).

Kaip vaikystės nostalgijos objektas pasakotojos atmintyje iškyla ir Permė („tipiškas carinès Rusijos pramoninis centras šiapus Uralo“ (49)). Sąmoningai išlaikant dvigubą fokusuotę (pasakotojos ir veikiančios subjektès vienu metu), tarsi nevertinančiu, tačiau ịdėmiu vaiko žvilgsniu stebima šio miesto aplinka ir fiksuojami įvykiai bei kasdienio gyvenimo detalès išryškina estetizuotą ir savotiškai nostalgijos retušuotą praeities vaizdą. Selektyvūs prisiminimai (iš pasakojimo dabarties pozicijos pasakotoja sąmoningai nefiksuoja tokių vaikui, rodos, „nereikšmingų“ dalykų kaip karas, badas ir skurdas) į pirmąji pasakojimo planą iškelia jusliškas ir emociškai nuspalvintas vaikystès patirtis:

Mano vaikiškon atmintin labiausiai įstrigo keli dalykai: tamsios medinès tvoros, pokšinčios nuo sauso šalčio, didelès vilko ir meškos skulptūros skvere prie teatro, ant kuriu ropšdavosi vaikai; bet labiausiai - skardinis rūsio stogelis po mūsu langu bei kieti, ant apvalaus pado siūbuojantys veltiniai ir ilgut ligutèlè žmonių eilè, lyg kokia gyvatè išsirangiusi baltame aikštès sniege - eile prie duonos ir pieno (50).

Savojo tapatumo pojūtis ir tuo pat metu buvimo ne savoje erdveje įspūdis (būdingas nostalginiams diskursams) pasakojime atskleidžiamas rekonstruojant gyvenimo Permèje fragmentą, kuriame subjektei stebint miestą ir žmones pirmą kartą patiriamas savo ir savo tèvų kitoniškumas, palyginti su tikraisiais permiečiais. Tëvų išsilavinimo, elgesio manierų, elegantiškos aprangos detalių atkūrimas pasakojime išryškina subjektès išskirtinumą vietinėje socialinejje aplinkoje ir tarsi apibrèžia priklausymą kitai - Lietuvos inteligentijos - socialinei grupei:

Žmonès Permèje dèvéjo standartinius, dažniausiai tamsius drabužius, atrodè panašūs vie-

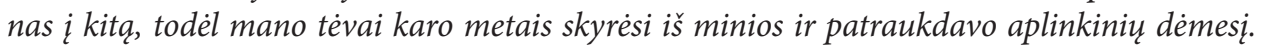
$<\ldots>$ Kiekvienas iš tolo maté, kad esam ne vietiniai. Ir elgèsi skirtingai (51).

Tapatumo tematinè linija A. Girdzijauskaitès pasakojime gana ryški ir susijusi su nostalgija. Pasakotoja, rekonstruodama vaikystės patirtis, fiksuoja ir socialinės aplinkos formavimąsi. Pavyzdžiui, aprašoma, kaip siekiant išlaikyti savajjị tautinị ir socialinį tapatumą Permèje natūraliai susikuria panašaus socialinio statuso, artimos pasaulèvokos žmones (kurių dauguma taip pat atvykèliai iš Lietuvos) jungianti mikrobendruomenè, kurios tarpusavio santykiai (susitikimai, pokalbiai, pasakojimai), kasdienès buities fragmentai, praeiti menantys daiktai, bendra nostalgija pasakojime tampa tiek individualaus, tiek kolektyvinio tapatumo reprezentacija.

Su vaikystės nostalgija glaudžiai susijęs pasakotojos siekis atmintyje atkurti ir užfiksuoti patirtą stiprų dvasinį ryšị su artimais žmonėmis. Emocinis nostalginis santykis su praeitimi išryškinamas ì pasakojamą istoriją ịvedant itin svarbias tèvo ir mamos Ancès figūras. Tẻvo figūra, kaip ir J. Vaičiūnaitès ar S. Lomsargytės-Pukienès pasakojimuose, čia atlieka

(48) $[8,145]$.

(49) $[8,8]$.

(50) $[8,8]$.

(51) $[8,19]$. 
reikšmingą - autoriteto ir mokytojo - vaidmenį. Jo laikysena ir veiksmai pasakotojos atžvilgiu ne tik simbolizuoja tam tikrą saugumo garantą, bet ir daro poveikị jos pačios projektuojamam gyvenimo modeliui. Atsiminimuose užfiksuojamas epizodas, kaip dvasinio ryšio su tèvu ir ilgesio vedama ị Permę subjektè grị̌žta dar kartą, jau suaugusi, kad galètų vèl pasivaikščioti tais takais, kuriais vaikystejje vaikščiodavo su tèvu, pasikalbèti su ji pažinojusiais žmonėmis, susigrąžinti prisiminimus ir per juos naujai išgyventi su tèvu praleistas akimirkas, tiek daug tuomet reiškusias mažai mergaitei ir tebereiškiančias dabar jau suaugusiai moteriai. Toks įvykių pakartojimas tiek vidiniame (intradiegetiniame) pasakojimo lygmenyje, tiek išoriniame (ekstradiegetiniame) lygmenyje rekonstruojant juos jau pasakojimo dabarties pozicijoje rodo ypatingą šių ịvykių svarbą ir vietą pasakojime.

Kita svarbi figūra - mama Ancè (namų šeimininkè, ekonomé, auklè - „ašis, aplink kurią viskas sukosi“ (52)), su kuria atsitiktinai susipažinta skverelyje prie Permès teatro, taip pat vaizduojama kaip neatskiriama ir reikšminga vaikystès dalis. Prisiminimai apie mamos Ancès gamintą žydišką maistą, ją supusius paslaptingus daiktus, pasakotas istorijas apie grafus ir jų kasdienybę i pasakotojos atmintị sugrąžina pasakišką, mitinę atmosferą, tada gaubusią vaikišką mergaitès pasaulį. Praeitị saugantys ir nostalgiją gaivinantys kasdieniai daiktai, atmintyje užsifiksavę ano laiko vaizdai ir kvapai pasakojime simbolizuoja kokybiškai kitokị gyvenimą, nebesugrąžinamą, tačiau savotiškai ịprasminantị ir dabarties būtị:

Dar dabar namie yra tos suneriamos lentutes paschos piramidei suformuoti - nors ir nereikalingos, bet neišmetamos, kaip ir dvi rantytos lentutes sviesto burbuliukams susukti paduodant i stala. Buvusio gyvenimo, kai mažiau skubèta, liudininkai... (53).

Visiškai kitoks santykis pasakojime atskleidžiamas pasakotojai prisimenant močiutę Anelę (motinos mamą), kuriai atsiminimuose tarsi atiduodama savotiška duoklè. Vis dèlto rekonstruojamas vaikystės fragmentas su vaikystès nostalgija neatrodo susijęs. Kupiškyje esantys močiutès namai, kur niekada iki tol nesilankiusi dešimtmetė vaikaitė atvežama atostogų, vaizduojami kaip svetima, nepažistama, nejauki erdvè, kurią kiek sušildo tik iš motinos pasakojimų atpažįstamos aplinkos detalès. Močiutès portretas kuriamas lakoniškai, tačiau ịtaigiai, charakterị atskleidžiant vos vienu kitu štrichu ar tinkamai parinkta fraze. Šias dvi giminystès ryšio siejamas, bet dvasiškai svetimas moteris skirianti distancija išryškinama pasakojimo fokusuotę perkeliant ị veikiančią subjektę, per jos vidines jausenas, patiriamas būnant močiutès namuose:

Man atrodè, kad aš čia gyvenu ne savo, o kažin kokị svetima gyvenima: saulejje spindintys altoriai, smidrai darželyje, nakties apgaubtas baugus miškas, išpiešta skrynia... Visa tai tikra, o kartu - nerealu, lyg sapnuočiau... (54).

Refleksyvi vaikystès nostalgija A. Girdzijauskaitès atsiminimuose natūraliai persipina su istorinių, kultūrinių praejusios epochos ženklų atkūrimu ir fiksavimu. Išskirtinis dèmesys detalèms iš kasdienybės tèkmès išgriebia ne tik konstruojamam „mažajam pasakojimui“, bet ir kolektyvinei atminčiai reikšmingus praeities fragmentus. Santūriai, be jokios patetikos ir deklaratyvaus vertinimo, bet tiksliai ir įtaigiai pasakotoja prikelia iš užmaršties kelių kartų (prieškario inteligentijos, karo ir pokario miestiečių) gyvenimo kultūros, tradicijų, buities vaizdus, išryškina nostalgijos persmelktą nesulaikomai kintančio erdvèlaikio atmosferą.

(52) $[8,79]$.

(53) $[8,79]$.

(54) $[8,101]$. 


\section{Silvija Lomsargytè-Pukienè. Dita: Paralelès (2004)}

"Grį̌siu ten, iš kur esu atèjusi.“"

S. Lomsargytè-Pukienè

S. Lomsargytès-Pukienès memuarinèje knygoje Dita: Paralelès (2004) aprépiamas gana ilgas pasakojamos istorijos laiko tarpas - nuo dabarties laiko grị̌tama iki pat XX a. pradžios ịvykių, fiksuojama net keturių kartų gyvenimo istorijų fragmentai kintančiame istoriniame fone. Vaizduojama dviplanè - miesto (Kauno, Vilniaus, Palangos) ir kaimo (Žvirgždaičių) - erdvè. Kuriamas originalus, daugiabriaunis pasakojimas, nostalgijos saitais susiejantis pasakotojos praeities patirčių refleksijas ir jų atspindžius dabarties pasaulèvokos perspektyvoje, atskleidžiantis asmeninès ir kolektyvinès dramos jungtis istoriniame praeities ịvykių kontekste, išryškinantis vertybinių, moralinių, dvasinių atspirties taškų ieškos procesą formuojantis ir kintant savojo tapatumo suvokimui. Intencija užrašyti prisiminimus pirmiausia iškyla asmeninès pareigos atminčiai pavidalu („Kas, be manęs, visa tai atsimins?" (55)), tačiau greta ryškèja ir natūralus noras užfiksuoti, ịprasminti ir pratęsti savąąą būtị $($ „<..> labiausiai noréčiau palikti tas mintis čia. Kad jos gyventų tuose, kurie lieka.“ (56)). Išreikšta pasakotojos pozicija savo reflektuojamo pasaulio ir jo vaizdinio konstravimo pasakojime (ryški valdymo funkcija) koreguoja išankstinius skaitytojų lūkesčius ir net sąlyginai apriboja potencialių adresatų ratą, tarsi nubrèžia savotiškas gaires tolesniam pateikiamo pasakojimo suvokimui:

Jei esate užsibrëžę labai aiškią riba tarp juoda ir balta, tarp praeities ir ateities, šiapus ir anapus - neskaitykite šios knygos. Neskaitykite ir tie, kurie tariatés Dieva suradę arba né nebandète jo ieškoti. Taip pat ir tie, kurie neabejoja, kad ju gentis, ju patirtis, tikëjimas, ju laimè ar nelaimé yra užvis svarbiausia (57).

Istorinio ir asmeninio laiko dimensijų persiklojimas ir susiliejimas, kategoriško vertinimo ir opozicinès sąvokų skirties nebuvimas, gyvenimo tikrovės efemeriškumas ir realiai apčiuopiama transcendencija - tai pagrindiniai šio memuarinio pasakojimo kūrimo principai. Praeitis čia rekonstruojama nesilaikant chronologiškos įvykių eigos, o sekant vidine pasakotojos logika ir atskirose pasakojimo atkarpose selektyviai iškeliant dabarčiai reikšmingas patirtis, žyminčias tapatumo ir dvasinès raidos etapus. Šio savotiško pasakotojos vidinių būsenų žemèlapio prasminėmis nuorodomis tampa Šventojo Rašto citatos, užsklendžiančios ir apibendrinančios kiekvieną pasakojimo fragmentą.

Kaip ir prieš tai analizuotuose memuariniuose pasakojimuose, pasakojamos istorijos lygmeniu veikiantys subjektai (artimiausių žmonių figūros) S. Lomsargytės-Pukienès atsiminimuose taip pat glaudžiai susiję su refleksyvia vaikystės nostalgija. Vis dèlto greta asmeninių santykių, kasdienès aplinkos refleksijų pasakotoja stengiasi išlaikyti ir apibendrinantị, svarstantị santykị su praeitimi iš dabarties suvokimo pozicijos bei ateities perspektyvos.

Rekonstruojamos vaikystès erdvès, i̇ kurias pasakotojos atmintị grąžina trapių, bet nenykstančią vertę turinčių dalykų ilgesys, - tai Kaunas (gimtasis miestas, tėvo artumo, vaikiškų džiaugsmų, pirmosios meilès vieta) ir Žvirgždaičių kaimas (pastovumą, saugumą ir amžinumą simbolizuojantys senelių namai; vieta, kur glūdi giminès šaknys ir pačios pasakotojos ištakos). „Prisimenant“ ankstyvąją vaikystę, kaip ir A. Girdzijauskaitès bei J. Vaičiūnaitès tekstuose, išskirtinis tèvo vaidmuo čia talpina pamatinius subjektès

(55) $[11,66]$.

(56) $[11,237]$.

(57) [11, tekstas ant knygos viršelio]. 
išskirtinumo, reikalingumo, saugumo ir tėviškos meilès lūkesčius, simbolizuoja pirminius ìvesdinimo ị gyvenimą ir tapatumo formavimosi užuomazgų momentus:

Savaime aišku, aš neprisimenu,kaip tèvas pirma sykị paima mane ant ranku, bet galiu lažintis - man buvo labai gera. <...> Taip pat žinau, kad tèvas išsyk pamilo mane ir mylejo iki paskutinio atodūsio. Žinau, kad tas atodūsis buvo panašus ị mano varda - Dita (58).

Ne tik šiame straipsnyje analizuojamuose tekstuose, bet ir apskritai kiekviename memuariniame pasakojime iškylančios kategorijos - subjekto aš ir ji tiesiogiai veikiantis kitas - tampa, literatūrologo Michailo Bachtino žodžiais tariant, vienas nuo kito neatsiejamais vertybiniais centrais, aplink kuriuos pasiskirsto bei išsidèsto visi konkretūs būties aspektai (59). Vidinị aš formuoja prisiminimai ir išgyvenamos būsenos (laimès, kančios, atgailos, troškimų ir siekių), tačiau išorinị (socialinị) savojo tapatumo suvokimą ir vertę, pasak teoretiko, subjektas gali patirti tik per šalia esantị kitą:

$<\ldots>$ pirmieji ir patys autoritetingiausi žodžiai apie ji [pasakojime veikianti subjektą - V. P.], pirmąkart iš išorès apibüdinantys jo asmenį, pasitinkantys jo vidinę tamsią savęs jauta, suteikiantys jai forma ir vardus, kuriais jis pirmąkart suvokia ir atranda save kaip kažka, yra mylinčio žmogaus žodžiai (60).

S. Lomsargytès-Pukienès pasakojime ryškinama socialinio subjektès tapatumo formavimosi trajektorija: jos socialinis savęs suvokimas pradeda formuotis Kaune, tuometinès inteligentijos apsuptyje, ir pasakojime natūraliai suvokiamas kaip neatsiejama šios rekonstruojamos (pasakojimo dabartyje nebeegzistuojančios) socialinès terpès ir kultūros dalis (knygos, teatras, privalomos pianino pamokos sudaro gyvenimo mieste rutiną, draugiją palaiko tarnaitė Janè - savotiškas A. Girdzijauskaitès mamos Ancès atitikmuo, ịkūnijantis nekintančią kasdienès buities tvarką ir namų jaukumą). Prieškario miestas pasakotojos atmintyje atgyja toks pat kaip ji visais pojūčiais užfiksavo vaikiška sąmonè - tviskantis Laisvės alejjos šviesomis, skambantis Danieliaus Dolskio melodijomis, kvepiantis migdoliniais pyragaičiais ir bandelèmis su cinamonu, viliojantis ịvairiausiomis gèrybėmis lenktyniaujančiomis parduotuvių vitrinomis. Vis dèlto iki galo išlaikoma nulinè fokusuotè - tarsi iš šalies stebèdama subjektès išgyvenamus vaikystès potyrius ir vengdama pernelyg sentimentalaus ir idealizuoto praeities vaizdinio, pasakotoja nuolat papildo ir koreguoja savo prisiminimus dabarties jzžvalgomis, pastabomis, komentarais. Taip prieštaraujant laikinei pasakojimo logikai leidžiama susitikti dviejose laiko (ir pasakojimo) plotmèse veikiančioms, bet tą patị asmenị ịkūnijančioms, subjektèms:

Andai, kai fontanas dar puikavosi auksinèmis žuvelèmis, o ne šiukšlèmis ir ne pilkomis monetomis, mergytè Dita pagarbiai stebèjosi nykštuko darbštumu.

Šiandien sena moteris Dita žiūri i jị su tokia pat baiminga pagarba. Sodelis ir memorialas atkurti beveik tokie pat kaip anksčiau. Sovietai buvo nušlavę nuo žemès paviršiaus visus kryžius, iš akmenu sukrauta paminklą, aukurą, Laisvès statulą. Tik nykštuko nelietė. Gal neatrodè pavojingas. Jis nereǐ̌kè jokių idejų (61).

Vaikystès miesto nostalgija S. Lomsargytės-Pukienès pasakojime neatsiejama nuo kintančio istorinio, kultūrinio Kauno fono (kareiviškų batų ir prasto muilo kvapas čia nustelbia cinamono dvelksmą, o prieškario inteligentijos spinduliuojamą šviesą pakeičia pokariu

(58) $[11,29]$.

(59) $[1,81]$.

(60) $[11,156]$.

(61) $[11,11]$. 
įsivyravęs „spekuliantų, sukčių ir kombinatorių miesto“ (62) vaizdinys). Prisiminimuose fiksuojama pasakotojos skausmingai išgyvenama miesto topografijos kaita karo ir pokario metais, atkuriamos išnykusios (išnaikintos) reikšmingos kolektyvinès atminties vietos ir simboliai (sovietmečiu sandèliu tapusi Šaričių bažnyčia; rusiškas tankas, „ne tik kaip paminklas, bet ir kaip grèsmingas priminimas, atsukęs patrankos vamzdị i „išvaduotos“valstybès užsienio reikalų ministro langą“ (63); Vytauto prospekto kapinès, paverstos nejaukiu "parku ne parku, skveru ne skveru“ (64)). Brèžiamos menamo (buvusio tada) ir realaus (esamo dabar) erdvėlaikio trajektorijos pasakojime susitinka, kryžiuojasi, persikloja, taip sukurdamos lyg ir tarpinị - vaiduoklišką, nostalgišką, supoetintą - erdvèlaikị (65):

Ir ko aš po penkiu dešimtmečiu sielvartingai glostau tą pajuodusią tvorą, kurios jau seniai neber? Vadinas, glostau ne ranka, o tik akimis, kurios ja gerai mato (66).

Tuo tarpu prisiminimuose apie Žvirgždaičius - pasakojamų ịvykių erdvę, kurioje praleistos visos subjektès vaikystės vasaros, - grąžinamos kaimo būties pirmapradžio pastovumo, universalumo ir amžinumo pajautos, apibendrinama igyta patirtis:

Čia gyventa protèviu jotvingių, ir protèviu protèvių, ir taip iki pat pradžios, kai čia įsikūrè žmonés. Čia išmokau skirti rugi nuo kviečio, sužinojau, kaip kepama duona, kaip kerpamos avys, kaip išsilukštena viščiukas ir nesukau sau galvos dèl to, kas buvo pirma - višta ar kiaušinis (67).

Senelių perduota patirtis ir dvasinès vertybès - meilè savo kraštui, žemei, namams, artimui - pasakojime atskleidžiama kaip tvarus saitas, jungiantis buvusias, esamas ir būsimas kartas bei užtikrinantis jų tęstinumą. Kartų tęstinumo simbolinę reikšmę išryškina ir sąmoningai brěžiamos praeities ir dabarties paralelès (nuo laiko parudavusioje senelių vestuvinèje nuotraukoje regèta miniatiūrinè puokštelè lygiai po šimto metų atgyja tokioje pat liaunoje anūkès (autorès dukters Eglès) rankoje jos vestuvių dieną - „Ir nusidriekia nematomas voratinklio siūlas iš 1900 metų ị 2000-ius“ (68); dar po kelerių metų saulès laidoje išnyrančios jau pačios subjektès vaikaičių figūrèlès visai tokios pat kaip jos vaikų, jų pačių, jų tèvų - „Du žmogučiai andai, ir du žmogučiai dabar, mūsų kūno ir dvasios tvariniai“ (69)). Ne tiek fizinio, kiek dvasinio ryšio su artimaisiais nenutrūkstamumas pasakojime perteikiamas per bambagyslès ịvaizdị, perkeliant jị i metafizinę plotmę - toji „bambagyslë“ jungia su sūnumi, išejusiu ị kariuomenę, vèliau ir su dukra, išvykusia ị Londoną. Nostalgija čia skleidžiasi per nuolat pasikartojantị išejjimo - (ne)grįžimo motyvą (išeinama iš namų, gimtojo kaimo; išeinama ị miestą, ị karą, kariuomenę ar tremti (priverstinę ar savanorišką); išeinama iš gyvenimo; išeina žmonès, angelai, namų dvasios - norima, žadama grịžti, dažniausiai negrị̌zama). Atsiminimuose gausu vaizduotès kuriamų metafizinių dialogų: ne tik su pačia savimi ar adresatu, bet ir su anapus išejusiais artimaisiais (tèvais, tarnaite Jane, tetomis Julija ir Prakseda), mistifikuotais pačios subjektès vidiniais personažais (angelu sargu, namų dvasia, baime - pilka skraiste apsigobusia ragana, persekiojančia visą gyvenimą), net praeitimi, kuri „issikimba ị padurką“ ir ragina viską

(62) $[11,16]$.

(63) $[11,16]$.

(64) $[11,117]$.

(65) Tokiu pat principu tarpinis tarp čia-dabar ir ten-tada erdvèlaikis kuriamas ir kitų šiame straipsnyje analizuojamų autorių pasakojimuose.

(66) $[11,181]$.

(67) $[11,56]$.

(68) $[11,33]$.

(69) $[11,213]$. 
prisiminti. Pasakotojos komunikacija su tuo, ko nebėra ar net niekada ir nebuvo, praeities nostalgiją paverčia susitikimo lūkesčiu („Dèl visa ko sakau ne sudie, o tik iki pasimatymo.“ (70)).

Kaip atskira pasakojamos istorijos tematinè linija S. Lomsargytės-Pukienès atsiminimuose išryškejja žydų tautos drama, asmeniškai palietusi ir pačią pasakotoją-subjektę. Dovydo žvaigždè, čia iškylanti ne tik kaip žydų tikejjimo simbolis, bet ir kaip pasmerktumo, neišvengiamo nuosprendžio, socialinio užribio ženklas, ì pasakotojos atmintị sugrąžina vokiečių okupacijos metais Kaune regètus vaizdus:

Žmonès su geltonomis Dovydo žvaigždemis retkarčiais praeina gatve. Gatve, ne šaligatviu. Šaligatviais eiti jiems užginta. Žmonès kaip iš kito pasaulio. Ne Kauno gyventojai. Ne mūsu vakarykščiai kaimynai (71).

Rekonstruojamos kolektyvinès holokausto tragedijos patirtys pasakotojos atmintyje tiesiogiai susijusios su skaudžiais asmeniniais išgyvenimais praeityje - senelio ir tèvo mirtimis, tuo metu nuolat persekiojusia grèsme ir baime dèl savo pačios žydiškos kilmės. Judejjiškos kultūros ir tikejimo atšvaitai, ženklinantys pasakotojos gyvenimą kaip tėvo giminès dvasinis palikimas, pasakojime atveria vertybinę, subjektyvias patirtis universalizuojančią plotmę. Čia gausu Šventojo Rašto citatų, žyminčių tiek individualią subjektès, tiek kolektyvinę visuomenès dvasinę raidą. Reikšmingi ịvykiai ar jausenos išryškinami per biblinius ịvaizdžius ir palyginimus. Atmintyje giliai ịstrigęs senelių persikèlimas iš kaimo ị miestą, skausmingai išgyventas savosios erdvès praradimas, S. Lomsargytės-Pukienès pasakojime prilyginamas išvarymui iš Rojaus:

Kraustymosi iš savos žemès, atsiplèšmo nuo savo šaknų, nuo savo stubų ir plyniu, nuo savo pasakiško šulinio su slypinčia jame vaivorykšte. Ǐ̌ẻimo, kuris nesibaigs grịžimu niekada (72).

Tuo tarpu vaiko akimis iš šalies stebèti masiniai trèmimai gretinami su kitu bibliniu motyvu - Nojaus arka:

Tas reginys priminè i Nojaus arką eilèmis einančius išsigelbèti įvairius gyvūnus. Vis po du, vis skirtingi. O čia beveik visi vienodi: arkliai-vežimas-vyrai-moterys-vaikai-karvès... Ir vèl: arkliai-vežimas-vyrai-moterys-vaikai-karvés... (73).

Amžiną laiko sukimąsi ratu, pulsuojantị gyvenimo ciklą ir atminties jègą („Ir vèl ieškai pradžios bei priežasties. Ir vèl pradedi iš naujo. Kaskart iš naujo.“ (74)) S. LomsargytèsPukienès pasakojime taip pat neatsitiktinai simbolizuoja dar vienas biblinis įvaizdis - vyro dovanota Jerichono rožè („Ir mano valioje jị vèl užmigdyti, atèmus tą vandens lašą." (75); „Ir mano valia vẻl ją prikelti, jei tik duosiu lašelị vandens.“ (76)). Biblinių ir istorinių siužetų gretinimas, ịvaizdžių, citatų, simbolių ịvedimas ị dabartyje rekonstruojamą gyvenimo istoriją perkelia pasakojimą i universalią, bendražmogišką dvasinès patirties plotmę.

\section{Gražina Mareckaitė. Šiapus ir anapus Vilniaus vartų (2009)}

„Esu tiktai Vilniaus ląstelè..."

G. Mareckaitè

G. Mareckaitès atsiminimų knygoje Šiapus ir anapus Vilniaus vartu (2009) nostalgijos objektas - prieškarinis Vilnius. Greta vidiniame pasakojamos istorijos lygmenyje

(70) $[11,236]$.

(71) $[11,95]$.

(72) $[11,60]$.

(73) $[11,110]$.

(74) $[11,216]$.

(75) $[11,218]$.

(76) $[11,224]$. 
rekonstruojamų individualių (vaikystės, namų, šeimos) prisiminimų išoriniame pasakojimo lygmenyje deklaruojamas ir siekis sugrąžinti ir išsaugoti su miesto praeitimi susijusią kolektyvinę atmintị, istorinius-kultūrinius praejjusios epochos ženklus. Be pagrindinès (naratyvinès), čia ryškios ir kitos pasakotojos funkcijos - valdymo, komunikacijos, liudijimo bei ideologinè. İžanginèje dalyje pasakotoja sąmoningai brèžia tam tikras pasakojimo gaires ir orientuoja numanomą adresatą aiškiai įvardydama savo poziciją ir tikètiną auditoriją, nusakydama pasakojimo konstravimo principą ir atskleisdama atsiminimų rašymo motyvus. Kaip vienareikšmiškai neigiamas dinamiškos ir multikultūriškos dabarties vertinimas nuskamba įvadinis teiginys, kad šis pasakojimas konstruojamas kaip priešingybè šiuolaikinei „klajūniškai“ pasaulèjautai ir filosofijai, siekiant „reanimuoti Vilniaus atmintị“ ir sugrąžinti „savojo miesto pojūtį, kurio dabartiniai miesto gyventojai neturi“, jog tai „sèslaus čiabuvio balsas, žodžiai „klajūnams“ ir bendrapiliečiams, kurie supranta, myli ar nuoširdžiai nori suprasti ir mylèti Vilnių“ (77). Kaip matysime, panašaus pobūdžio kategoriškų vertinimų ir sentimentalaus, vietomis net patetiško praeities ilgesio persmelktas ir visas tolesnis diskursas.

G. Mareckaitès atsiminimuose pasakojamų ịvykių laikas yra dviplanis: rekonstruojamas prieškarinis Vilnius (su šio laiko dvasia, kultūra ir žmonėmis pasakotoja tapatinasi) ir paraleliai, kaip kontrastas pirmajam, vaizduojamas pokarinis, sovietų okupuotas miestas (pasakotojos atmetamas kaip svetimas). Toks dichotomiškas Vilniaus vaizdinys kuriamas ne tik gretinant vieno ir kito laiko sandūroje kintančias gyvenimo detales, bet ir ryškinant dviejų pasakojimo erdvès ir laiko plotmių susikirtimo taškus. Aiški skirtis brěžiama per visus rekonstruojamo gyvenimo būdo segmentus: kategorizuojant pačius žmones (vilniečiai - gyvenę Vilniuje prieš karą, „kentèję ir kovoję dèl lietuvybės išlaikymo senojoje sostinejje ir visame Vilniaus krašte“ (78) ir nevilniečiai - kiti Vilniaus gyventojai), jų išvaizdą (senieji gyventojai pirmųjų Vilniaus fotografų nuotraukose subjektei atrodo „kitokie negu mes. Tauresni. Orūs. Santūrūs. Padorūs.“ (79)), aprangą („Visi daiktai mamos spintoje buvo iš ten. Jie kvepèjo, šiugždejo, buvo meilūs, minkšti, pūkuoti ir glotnūs.“ (80)), namus (sovietmečiu „dèdienès namai neatpažǐstamai pasikeitè: veidrodžiai, paveikslai, kilimas, net laikrodis buvo nusukti ị sieną, todèl galejai matyti tik vinimis pritvirtintą, maišine drobe aptrauktą išvirkščiąją daiktų pusę. Jokios prabangos, jokio blizgesio, jokių spalvų!“ (81)), miesto architektūrą („Ivairiaspalviai langai tyliai, be protesto ir dramatiškų dužimo scenų užleido vietą kitos kultūros elementams - fanerai, kartonui, pakuliniams kamščiams, lentelèms nuo taros dèžių. “ (82)). Pasakotojos, kuri tampa tarsi dabartyje besitęsiančios praeities mediume, nostalgija negrižtamai praejjusiam laikui ị realią (pasakojimo dabarties) Vilniaus erdvę perkelia senosios praeities vaiduoklius (persipina ir sluoksniuojasi realusis ir mitinis erdvèlaikiai). Pasakotojai svarbių praeities personažų „veikimas“ šioje paralelinėje erdvėje igauna ir tam tikrą ideologinę, vertybinę išraišką (Užupio kieme ir Bernardinų sode ji sutinka Antano Vivulskio šešèli, Jono Basanavičiaus gatvẻje - „tauraus profilio barzdotą vyrą su pensne, ilgu paltu, elegantiška skrybèle“ (83), o prie Aušros Vartų - seniai išmirusius ar pasklidusius po pasauli artimuosius).

(77) $[12,8]$.

(78) $[12,24]$.

(79) $[12,40]$.

(80) $[12,78]$.

(81) $[12,44]$.

(82) $[12,68]$.

(83) $[12,114]$. 
Mitinę (iliuzinę) pasakojimo plotmę papildo ir jusliškos, asociatyvios atminties projektuojami estetizuoti ir mistifikuoti vaikystès vaizdiniai. Poetiška sakinių ritmika, romantizuotas, vietomis net patetiškas santykis su praeitimi žymi refleksyviosios nostalgijos dominantę ankstyvuosiuose prisiminimuose. Iš pasakojimo dabarties pozicijos reflektuojamas vaikystès pasaulis begalinio ilgesio šviesoje igauna idealaus būvio pavidalus: angelas sargas čia lydi mažą mergaitę ir saugo ją nuo pavojų, pasaulis pro vitražų stiklus žaižaruoja visomis spalvomis, vaikystės metų laikai kupini vivaldiškų jausenų (vasaros - bekraštès ir begalinès, „jokiais kalendoriais ir klepsidromis neišmatuojamos“, rudenys - „tirštas ir vaiskus medus“, žiemos - „žèrintis sniegas, pušų šakose siaučiantis vejjas ir trumpos dienos pabaigoje ịsižiebiančios žvaigždès“, o pavasariai - „liuminescencinis klevų žydejjimas, kalnai alyvų, geltonos tulpès, agrastų žaluma ir plakantis sparnais drugelis tarp lango stiklų“), o senasis Vilnius ir jo gyventojai persmelkti paslapties. Vaikystės nostalgija, stipriai kontrastuojanti su nepasitenkinimą ir nusivylimą keliančia dabartimi, atrodo tokia stipri ir užvaldanti, kad jai pateisinti ir tarsi patvirtinti šios būsenos visuotinumą pasakotoja pasitelkia kitų buvusių vilniečių, taip pat vaizduoteje, sapnuose ir svajonèse nuolat grižtančių ị tas pačias miesto erdves, prisiminimus (prieškario Vilniaus fotografo Jano Bułhako, rašytojo Tadeuszo Konwickio):

Kokia saldi paguoda buvo patirti, kad ne aš viena ilgiuosi, ne aš viena kankinuosi, ne vien mano siela serga nepagydoma šio Vilniaus kampo nostalgija... (84).

Pasakotojos komunikacija su kolektyvine atmintimi, savotiškas siekis objektyvizuoti savo individualias patirtis rodo laipsnišką perejjimą nuo refleksyviosios link atkuriančiosios prarastojo laiko nostalgijos. Vilniaus nostalgija G. Mareckaitès pasakojime reprezentuojama kaip neišvengiama kiekvieno „tikro vilniečio“, erdviškai ar laikiškai praradusio ši miestą, jausena. Pasakotoja tapatinasi su, jos manymu, tokiais pat besiilginčiais („Visi jie man kaip sielos broliai.“ (85)) - ši bendrystè leidžia jaustis neatskiriama atmintyje gyvo ir pulsuojančio drauge su besikeičiančiu laiku miesto bei jo sociumo dalimi.

Tautinio, socialinio tapatumo ženklai pasakojime atskleidžiami per glaudžią sąsają su miestu ir jo simboliais. Pristatant formalią ir kintančią pasakotojos-subjektès tapatybę (Lenkijos piliete் - Lietuvos pilietè - sovietų Lietuvos pilietė) deklaruojamas aiškus savęs kaip lietuves vilnietés suvokimas, ịsišaknijęs giminėje iš kartos ị kartą kaip būties imperatyvas:

Pro vartus, lydimi švelnaus Marijos žvilgsnio, nukeldami kepure, dienu dienas, metu metus, ištisus dešimtmečius, - pavasariais, vasarom, rudeniais, žiemom, - prieš kara, per kara, po karo, - darganoje, šaltyje, kaitroje, lietuje, pūgoje, - varguose, skausmuose, džiaugsmuose <...>, ejjo ir èjo visi mano giminès, mano šeimos vyrai, moterys, seniai, vaikai (tarp jų ir aš) (86).

Skirtingų, vienas su kitu kontrastuojančių laikmečių, jų istorinių ir kultūrinių ženklų apraiškas atskleidžiančių kūniškumo reprezentacijų kaita G. Mareckaitès pasakojime iš dabarties perspektyvos sąmoningai ryškinama kaip savotiškas „kovinis laukas“. Prieškario vilniečių išvaizda, apranga ir manieros, kurias pasakotoja detalizuoja neslëpdama susižavèjimo, demonstruoja subtilų skonị, orumą, mažesnę ar didesnę prabangą, laisvą ir pasitikinčią savimi laikyseną. Tuo tarpu sovietinès okupacijos metu vietoj buvusios tiesioginès, nuo išorès aplinkybių nepriklausomos individualios reprezentacijos iškyla kolektyvinio maskavimosi, savojo tapatumo slèpimo, atrodymo kitu negu yra iš tiesų elementai. Pavyzdžiui, pasakojamoje istorijoje veikiantys dẻdè ir dẻdienė „užèjus rusams“ maskuoja savo priklausymą buržujų klasei ne tik namuose visus daiktus laikydami išvirkščiąa puse, bet ir

(84) $[12,11]$.

$(85)[12,8]$.

(86) $[12,30]$. 
nešiodami išverstus drabužius. Toks žaidimas tapatumo reprezentacijomis ir falsifikuotais ivvaizdžiais pasakojime leidžia sukurti savotišką prisitaikymo prie pokarinio Vilniaus diktuojamų gyvenimo sąlygų spektaklį:

Marija Płucińska-Žižmariene iš Gendzvilu - tikra daržo kaliausè. Jos prieškarinè brangi skrybèle išversta pamušalu ị viršu, pamušalo puse išversti ir kailiniai, blauzdos apmuturiuotos šalikais - kas tokia plèš? (87).

G. Mareckaitès memuariniame pasakojime itin reikšmingas (tiek istorinis, tiek metafizinis ir simbolinis) vaidmuo skiriamas Aušros Vartams. Vidiniame pasakojamos istorijos lygmenyje tai - vaikystès priemiesčius ir istorinị-kultūrinị miestą skirianti riba. Aušros Vartai yra ta vieta, kur prasideda ir baigiasi „tikrasis Vilniaus miestas“, kur susitinka „draugai ir priešai, karaliai ir didikai, pirkliai ir valkatos, kareiviai, vagys, plěšikai ir kiti“, kur grịžtama po ilgos kelionès ar net mirties. Tuo tarpu išoriniame pasakojimo lygmenyje šie vartai tampa lyg ir savotiška simboline skirtimi tarp pasakotojos juslinės autobiografinès atminties ir siekiamos atkurti kolektyvinès istorinès atminties. Emocines vaikystès refleksijas, kurioms būdinga poetinè raiška (gausu retorinių figūrų, pakartojimų, palyginimų, metaforų ir pan.), čia keičia į objektyvumą orientuotas svarbių istorinių praeities ịvykių fiksavimas, kiek santūresni miestui reikšmingų kultūros asmenybių, architektūros paminklų (sunaikintų ar taip ir likusių tik projektuose) aprašymai.

Atkuriant istorinio-kultūrinio Vilniaus fragmentus fiksuojama urbanistinių ir gamtos detalių dermé, pasakojimo dabarties pozicijoje pasakotojos vertinimu vis labiau artejanti link disharmonijos: bažnyčių varpai, be kurių skambejjimo miestas tapo nebylus („Kad ir koks sunkus, sumaištingas buvo šio „miesto tarp audrų“ likimas, vilniečių sielos ir akys nešliaužiojo pažemiais, o žvelgè ị dangų, kilo aukštyn, nes rytą, vidurdienį, vakarą mieste iškilmingai ir melodingai gaudè bažnyčių varpai. Jie drąsino, guodè, ramino, pasitikdavo ir išlydèdavo. Paskui nutilo.“ (88)) ir kalvos, dabar jau tik menančios didvyriškus ir tragiškus „vilnietiškus laikus“; pasmerkti išnykimui kaštonai („<...> jie tikri aristokratai, didikai, susirinkę ị taurią pavasario puotą. Baltais garbanotais perukais, kvepiantys pavasario lietum, garbieji ponai šoka menuetą ir gavotą, šnekasi tik jiems vieniems suprantama kalba." (89)) ir senamiesčio bokštai, kurių „paauksuotos karūnos, grakštūs gulbių kaklai, smailos kepurès su ažūrinių kryžių tiaromis“ aštriai disonuoja su modernaus šiuolaikinio miesto architektūrinèmis tendencijomis („primityviausiais dangoraižiais ir šleivu Mindaugo tiltu“).

Iš atskirų fragmentų, detalių, prisiminimų nuotrupų ir akimirksnio potyrių rekonstruodama grimztančio ị nebūtị prieškarinio Vilniaus vaizdinị, pasakotoja, tarsi siekdama kiek nugludinti savo prisiminimų subjektyvumą, pasitelkia ir papildomą praeities laiką liudijančią medžiagą - motinos Veronikos Žižmaraitės-Mareckienès gyvenimo istorijos nuotrupas, tèvo Petro Marecko užrašus, tų laikų fotografijas. Vis dèlto nepaisant šių pastangų bent kiek objektyvizuoti pasakojimą itin ryškus kategoriškas vertinimas („Prieš karą viskas buvo geriau, gražiau, nepaprasta.“ (90)) ir tikslinga komunikacija su skaitytoju, tarsi apeliuojant ị jo su(si)pratimą („Vilniečiai, paskubèkite! Galbūt tai paskutinis jūsų šansas - 2009-aisiais pamatyti žydinčius Vilniaus kaštonus!"), atskleidžia švietėjiškumo intenciją ir prisiimtą savotišką praeities miesto "gelbètojos“ misiją (kitaip tariant, ideologinę pasakotojos funkciją).

(87) $[12,44]$.

(88) $[12,58]$.

(89) $[12,61]$.

(90) $[12,77]$. 


\section{IŠVADOS}

Memuaristiką vertinant ne tik kaip papildomą istorinị, informacinį šaltinį, bet ir kaip lygiavertį literatūros žanrą, atsiveria kitokios metodologinių tyrimų prieigų galimybès. Greta istorikų, kultūrologų, sociologų plačiai taikomos memuarinio pasakojimo turinio analizès tampa galima literatūrologinè pasakojimo formos, arba diskurso, analizè. Diskursyvinès raiškos ịvairovė lietuvių memuariniuose tekstuose iš esmès leidžia išskirti tris atskiras grupes pasakojimų, atitinkančių rusų literatūrologo I. Fraimano pasiūlytą tipologiją. Deskriptyvaus pasakojimo strategija būdinga objektyvaus liudijimo ịspūdị kuriantiems istoriniams-kultūriniams memuarams. Čia pasakojimo ašimi tampa ne tiek pasakotojas, kiek pasakojimo objektas. Rekonstruojant praeities laiką laikomasi ịvykius ir jų istorinị, kultūrinị bei socialinị kontekstą vertinančios, apibendrinančios pasakotojo pozicijos iš dabarties perspektyvos. Memuaruose, kuriuose atsiskleidžia itin ryškus nostalginis subjekto santykis su praeitimi, dominuoja naratyvinė pasakojimo strategija. Čia žvilgsnis nukreipiamas ị pasakotoją ir jo tapatumo formavimąsi tam tikromis aplinkybèmis, ị pirmą pasakojimo planą iškeliamos subjektyvios individualios patirties refleksijos. Trečioji memuarinių tekstų grupẻ atitiktų tikslingo arba nukreipto į tiesioginę skaitytojo reakciją pasakojimo strategiją, susijusią su autoriaus reputacijos ar naujo tapatumo kūrimu ir ịtvirtinimu, siekiant pateisinti praeityje padarytus veiksmus, pasirinkimus ar sprendimus, arba siekimu atstatyti tam tikrą istorinị teisingumą, liudijant ir išsaugant kolektyvinèje atmintyje traumines (karo, tremties, holokausto) praeities patirtis.

Nostalginiams naratyvinio tipo memuarams priklausantys J. Vaičiūnaitès, A. Girdzijauskaitès, S. Lomsargytės-Pukienès ir G. Mareckaitès pasakojimai atveria subjektyvaus, emocinio, jusliško kalbejjimo apie praeities laiką plotmę. Jiems būdingas atidus dėmesys kasdienès aplinkos ir buities detalèms, socialinių santykių raiškai, individualaus tapatumo transformacijoms. Erdvèlaikio ir subjekto egzistencijos dichotomija čia ryškinama paraleliai brěžiant menamo (buvusio tada) ir realaus (esamo dabar) erdvėlaikio trajektorijas, kurios pasakojime susitinka, kryžiuojasi, persikloja, išplėsdamos išorinio, pirminius siužetinio pasakojimo rèmus sudarančio erdvèlaikio ribas ir sukurdamos tarpini - mistifikuotą, efemerišką, iliuzinị - vidinị erdvèlaikį. Subjektas, atsidūręs dviejų erdvèlaikių, istorinių epochų, viena kitą keičiančių kultūrų sankirtoje, taip pat patiria savotišką tarpinès egzistencijos būseną. Prarastasis objektas (praẻjęs laikas) nostalgijos šviesoje iškyla kaip tvarus gyvenimo pagrindas, kurio dabartis subjektui užtikrinti negali. Refleksyviosios nostalgijos raiška ypač būdinga ankstyviesiems vaikystès prisiminimams.

Gauta 20140715

Priimta 20150511

\section{Literatūra}

[1] BACHTINAS, Michailas. Autorius ir herojus: estetikos darbai. Vilnius: Aidai, 2002. 439 p.

[2] BAL, Mieke. Narratology: Introduction to the Theory of Narrative. Toronto, Buffalo, London: University of Toronto Press, 1997. 254 p.

[3] BARTAS, Rolanas. Teksto malonumas. Vilnius: Vaga, 1991. 339 p.

[4] BOYM, Svetlana. The Future of Nostalgia. New York: Basic Books, 2001. 432 p.

[5] DAUJOTYTE், Viktorija. Parašyta moterų. Vilnius: Alma litera, 2001. 840 p.

[6] ФРАЙМАН, И. Д. Русские мемуары в историко-типологическом освещении. К постановке проблемьь. „Цепь непрерывного предания... “: Сборник памяти А. Г. Тартаковского. Москва, 2004. 346-361 p. 
[7] GENETTE, Gerard. Narrative Discourse: An Essay in Method. Ithaka, New York: Cornell University Press, 1983. 275 p.

[8] GIRDZIJAUSKAITĖ, Audronè. Atminties salos. Vilnius: Lietuvos rašytojų sąjungos 1-kla, 2008. $152 \mathrm{p}$.

[9] ISER, Wolfgang. Fiktyvumas ir įsivaizdavimas. Vilnius: Aidai, 2002. 275 p.

[10] ISER, Wolfgang. The Act of Reading: A Theory of Aesthetic Response. Baltimore, London: The Johns Hopkins University Press, 1978. 231 p.

[11] LOMSARGYTĖ-PUKIENĖ, Silvija. Dita: Paralelés. Kaunas: Jotema, 2004. 240 p.

[12] MARECKAITĖ, Gražina. Šiapus ir anapus Vilniaus vartų. Vilnius: Naujos sistemos, 2009. $118 \mathrm{p}$.

[13] NORA, Pierre. Pasaulinè atminties viešpatija. Iš: Europos kultūros profiliai: atmintis, tapatumas, religija. Vilnius: Kultūros barai, 2007. p. 9-23.

[14] NOTRIMAITE், Gitana. Atminties imperatyvai. Vilnius: Lietuvių literatūros ir tautosakos institutas, 2010. $263 \mathrm{p}$.

[15] SMITH, Sidonie; WATSON, Julia. Reading Autobiography: A Guide for Interpreting Life Narratives. The University of Minnesota Press, 2001. 392 p.

[16] VAIČIŪNAITĖ, Judita. Mabre viešbutis: memuarinė proza. Vilnius: Lietuvos rašytojų sąjungos 1-kla, 2009. $152 \mathrm{p}$.

VILMA POPOVIENÉ

\section{Nostalgia discourse in Lithuanian memoirs}

Summary

The present paper analyses discourse strategies in the Lithuanian memoirs on the basis of the Russian literature theorist Ilon Fraiman's theoretical insights and suggested typology of memoirs. According to the specifics of the genre a modified narratological methodological approach is applied. Discourse is understood here as a whole of metanarration fragments consisting of memoirs intentionality and the narrator's approach to describing events, the time gap between the narration and the narrated events, internal (author-narrator-subject) and external (author-reader) communication. Svetlana Boym's study on the nostalgia and its theoretical aspects is relevant to the analysis of the memoirs, where the aspect of nostalgia is very intense and basically acts in its discursive expression. In order to reveal the author's (narrator's, subject's) relation with the object of narrative, nostalgia is examined as a specific aspect of the memory and the imagination at the same time. In the mind of the subject nostalgia arises in various forms - as an indirect experience, forming subject's approach to the past, and as the subject's status, which unfolds reflexive meditation and painful longing for the phantom object, or restoration of the past, not only in the individual, but also in the collective memory.

Key words: memoirs, narrative, discourse strategy, nostalgia, memory 